This item was submitted to Loughborough's Research Repository by the author.

Items in Figshare are protected by copyright, with all rights reserved, unless otherwise indicated.

\title{
Contextual determinants of employee entrepreneurial behavior in support of corporate entrepreneurship: a systematic review and research agenda
}

PLEASE CITE THE PUBLISHED VERSION

https://doi.org/10.1142/S0218495818500115

\section{PUBLISHER}

(c) World Scientific Publishing

\section{VERSION}

AM (Accepted Manuscript)

\section{PUBLISHER STATEMENT}

Electronic version of an article published as Journal of Enterprising Culture, 26 (3), pp.285-326. doi: $10.1142 / S 0218495818002085$ @ [copyright World Scientific Publishing Company] https://www.worldscientific.com/worldscinet/jec

\section{LICENCE}

CC BY-NC-ND 4.0

\section{REPOSITORY RECORD}

Mustafa, Michael, Fiona Gavin, and Mathew Hughes. 2019. "Contextual Determinants of Employee Entrepreneurial Behavior in Support of Corporate Entrepreneurship: A Systematic Review and Research Agenda". figshare. https://hdl.handle.net/2134/35314. 


\title{
Contextual Determinants of Employee Entrepreneurial Behavior in Support of Corporate Entrepreneurship: A Systematic Review and Research Agenda
}

\author{
Michael Mustafa \\ University of Nottingham Malaysia \\ Mathew Hughes \\ Loughborough University \\ Fiona Gavin
}

University of Nottingham

\begin{abstract}
The individual entrepreneurial behavior of employees represents one of the primary antecedents of Corporate Entrepreneurship. The complex nature of 'employee entrepreneurial behavior' suggests that a myriad of contextual influences act on the emergence of such behavior. It is imperative that theorists and practitioners alike understand both the subtle and sophisticated ways in which context influences employee entrepreneurial behavior. To address these issues and encourage future work, this study performs a systematic literature review to provide an overview of the field and examines the influence of the job/role, organizational/work and external contexts on employee entrepreneurial behavior. Findings suggest that employee entrepreneurial behavior is an emergent research field and that its behaviors can manifest themselves in different ways compared to firm-level entrepreneurial behaviors. We also show the sophisticated manner in which different types of context influence employee entrepreneurial behavior.
\end{abstract}

Keywords: Entrepreneurial Behavior; Corporate Entrepreneurship; Intrapreneurship; Strategic Entrepreneurship; Review; Systematic Literature Review; Employee 


\begin{abstract}
Author Information
Michael Mustafa**

Nottingham University Business School The University of Nottingham Malaysia Campus Jalan Broga, 43500 Semenyih, Selangor, Malaysia. Email: michael.mustafa@nottingham.edu.my
\end{abstract}

\title{
Fiona Gavin
}

Faculty of Medicine \& Health Sciences

Nottingham University Jubilee Campus

Wollaton Road

Nottingham NG8 1BB

United Kingdom

Email: fiona.gavin@nottingham.ac.uk

\section{Mathew Hughes}

School of Business and Economics

Loughborough University

Loughborough LE11 3TU

United Kingdom

Tel.: +44 (0) 1509223263

Email: m.hughes2@lboro.ac.uk

**Corresponding author 


\section{Introduction}

Entrepreneurial activity has long captured the interests of scholars (Audretsch, 2012; Busenitz et al., 2003) as it positively relates to innovation, new venturing, employment growth and social and economic value creation (Bird, 1983). Entrepreneurial activity is not only limited to new small independent ventures (Hughes and Morgan, 2007; Shane and Venkataraman, 2000; Wiklund et al., 2011) but may also take place in established organizations via the extent to which they take risks, innovate and act proactively (Miller and Friesen, 1983). Employee entrepreneurial activity is fundamental to achieving and sustaining corporate entrepreneurship, yet it remains one of managers' most puzzling problems: how can managers change the behaviour of employees to enable and sustain entrepreneurship and innovation?

Traditionally, studies of firm-level entrepreneurship have focused on the organizational antecedents of such activity (Wales, 2016). Along with this line of inquiry, there is growing recognition of the importance of employee activity in in enabling and sustaining firm-level entrepreneurship (Hornsby et al., 2009; Monsen and Boss, 2009; Wales, Monsen and McKelvie, 2011). However, compared to research on the individual and organizational factors that drive firm-level entrepreneurship, research examining the individual entrepreneurial actions or behaviors of employees remains disparate and scarce (Lau et al., 2012). Central to this problem is looseness over the definition of 'employee entrepreneurial behavior' and a lack of synthesis over its nomological network and system of effects and contingencies. Such limited research has prevented scholars from developing a more detailed understanding of employee entrepreneurial behavior, what conditions this behaviour, and how this behavior ultimately informs and supports firm-level entrepreneurship. Without answers to these problems, scholars remain frustratingly unable to answer the management puzzle of how employees can be actively involved in 
corporate entrepreneurship. Consequently, we believe that a systematic overview of existing research into employee entrepreneurial behavior is highly warranted to provide scholars a detailed overview of the field and in devise ways of expanding and moving the field forward.

While the decision to engage in entrepreneurial behavior is a personal one (Kuratko et al., 2005), a myriad of forces arising from the "context" in which their actions take place in (Zahra and Wright, 2011) influence employees. Therefore, besides personal factors, employees’ entrepreneurial behavior can be influenced by a range of contextual determinants (Rigtering and Weitzel, 2013). Research has acknowledged the importance of context in explaining entrepreneurial actions and their outcomes (Bjørnskov and Foss, 2013; Zahra and Wright, 2011). Contextual influences are believed to pervade and influence the micro-processes that give rise to entrepreneurial actions. While, studies have looked disparately at various organizational (Kuratko et al., 2005) and work (Rigtering and Weitzel, 2013) factors of employee's entrepreneurial behavior, there has yet to be a detailed overview of the different types of context and how they influence such behavior. This study seeks to bridge this gap through a systematic literature review of the current state of research in the field of employee entrepreneurial behavior and by examining how employees’ job/role, organizational/work and external environmental contexts both independently and simultaneously influence such behavior. In doing so, we respond to calls by scholars to further account for context in the determination of entrepreneurial behavior (Arz, 2017; Zahra and Wright, 2011). Accordingly, we seek to address the following research questions:

RQ1: What is the current state of knowledge concerning employee entrepreneurial behaviors in pursuit of Corporate Entrepreneurship (CE)? 
RQ2: What are the contextual determinants of employee entrepreneurial behaviors in established organizations?

Our study contributes to the existing literature in several ways. Firstly, we respond to calls in the Corporate Entrepreneurship literature to clarify how entrepreneurial process emerge in established organizations. Specifically, our SLR represents one of the first attempts in the literature to provide a comprehensive overview of employee entrepreneurial behavior research. Secondly, by providing a fine-grained content analysis of the contextual determinants of employee entrepreneurial behavior, our study deepens the existing literature's understanding of the complex forces that influence such behavior (Amo and Kolvereid, 2005; Arz, 2017; Hornsby et al., 2009; Rigtering and Weitzel, 2013). Finally, in developing our model and suggestions for future research, our study provides fresh insights into how future researchers can advance the field of employee entrepreneurial behavior.

The paper is structured as follows. The following section provides the theoretical foundations that differentiate between employee entrepreneurial behavior, Corporate Entrepreneurship (CE) and intrapreneurship. In doing so we also provide a working definition of employee entrepreneurial behavior. Next, we describe in detail the rationale and procedure used in conducting our SLR. This is followed by an overview of the current state of research on employee entrepreneurial behavior research along with the contextual determinants of such behavior. A theoretical model from our findings and provide a discussion of the existing research and suggestions for future research follows. The paper concludes with a discussion concerning the implications for theory and practice based our review of the results. 


\section{Conceptualizing Corporate Entrepreneurship and Employee Entrepreneurial Behavior}

Firm-level entrepreneurship can have significant financial and strategic benefits for firms operating in hostile and dynamic/turbulent environments (Covin and Slevin, 1989; Kraus et al., 2012). Concepts such as corporate entrepreneurship, corporate venturing, entrepreneurial orientation and intrapreneurship have been used to describe firm-level entrepreneurship (Urbano and Turro, 2013). In providing an overview of the field, Antoncic and Hisrich (2003) identified two principal streams of research (entrepreneurial orientation (EO) and the Corporate Entrepreneurship (CE) approaches) at the organizational level. In this particular study, we focus on the CE approach. Sharma and Chrisman (1999, p. 18) define CE as: "the process whereby an individual or a group of individuals, in association with an existing organization, create a new organization or instigate renewal or innovation within that organization”. Broadly, CE can result either in corporate venturing (CV) or strategic entrepreneurship (Kuratko and Audretsch, 2013) or both.

Corporate venturing describes the various methods for creating, adding to, or investing in new businesses (Kuratko and Audretsch, 2013) which allow organizations to build their innovative capability, expand their scope of operations and knowledge, and generate financial returns (Kuratko, Hornsby and Hayton, 2015). Such venturing activities may be either internal or external in nature (Abrell and Karjalainen, 2017; Narayanan, Yang and Zahra, 2009). Strategic entrepreneurship refers to a broad array of entrepreneurial activities adopted in the firm's pursuit of competitive advantage, but which does not usually result in new businesses for the corporation. Strategic entrepreneurship can take one of five forms—strategic renewal (adoption of a new strategy), sustained regeneration (introduction of a new product into an existing 
category), domain redefinition (reconfiguration of existing product or market categories), organizational rejuvenation (internally focused innovation for strategy improvement), and business model reconstruction (redesign of existing business model), (Covin and Miles, 1999)

Typically, CE is studied as 'top-down' processes related to the creation of corporate change, renewal and flexibility through a managerial disposition towards innovative, proactive and risk-taking behaviors (Covin and Slevin 1989; Lumpkin and Dess 1996; Rauch et al., 2009). However, entrepreneurial activity can happen at all levels throughout the organization and may also occur through the self-initiated activities of individuals performed with or without organizational permission (de Jong and Wennekers, 2008; Wales et al. 2011). The term ‘intrapreneurship' has been used to describe such entrepreneurial activities which are pursued in a bottom-up manner by employees within organizations (Åmo and Kolvereid, 2005; Rigtering and Weitzel, 2013). Intrapreneurship is premised on the idea that valuable human capital resides in entrepreneurial employees within organizations (Guerrero and Peña-Legazkue, 2013). The characteristics of human capital, observable through intrapreneurial behavior, provide a bridge between intrapreneurship and CE, regarding CE either as a desirable outcome from the firm's senior management initiatives or as intrapreneurship from the self-determined behavior of employees (Åmo and Kolvereid, 2005).

Both CE and intrapreneurship have been used interchangeably in the literature, leading to significant confusion. For instance, Sharma and Chrisman (1999), viewed intrapreneurship as a form of CE while Camelo-Ordaz et al. (2012) explicitly refer to intrapreneurship as employees who "recognizes opportunities and develops innovations from within an existing hierarchy" (p. 3). In this study, we follow Sharma and Chrisman (1999) and view intrapreneurship as a form of CE. We view CE as a breeding ground for intrapreneurship and vice versa, as both 
organizational factors and the individual self-determined behavior of employees are necessary to enable entrepreneurial behavior (Åmo and Kolvereid, 2005). Ireland, Covin, and Kuratko (2009) suggest that such entrepreneurial behaviors and activities of employees are critical to any corporate entrepreneurship strategy.

Research at the firm-level has typically conceptualized CE as a set of innovative, proactive and risk-taking behaviors (see Covin and Slevin, 1989; Rauch et al., 2009) essential for recognizing opportunities and the reconfiguration of resources to exploit those opportunities. Some scholars have also viewed these three dimensions as crucial elements of employees' entrepreneurial behavior as well (de Jong et al., 2013). However, behaviors at the individual level may be distinct from those at the firm-level. It is highly likely that individual behaviors will probably aggregate to inform firm-level activities (Lau et al., 2012). For instance, in addition to the creation of new ventures on behalf of their employer, employee's entrepreneurial behavior can be broader in nature and also include ideas for new product development, process and administrative improvements, or work role innovations (de Jong et al., 2013). Hence, firms will only be innovative to the extent that its human resources are innovative. Based on the existing literature this study recognizes that employee entrepreneurial behavior is distinct from firm-level entrepreneurial behavior and should be treated as such.

Research has shown that management hierarchies cannot be assumed to perform homogenous functions (Hornsby et al., 2009; Mustafa, Martin and Hughes, 2016). For example, King, Fowler, and Zeithaml (2001) identified that middle-managers tend to reconcile top management's perspectives with the implementation issues that appear at lower management levels. Additionally, top management is primarily concerned with strategic decisions, while lower-level management is concerned with implementing directives from middle managers 
(Floyd and Wooldridge, 2007). This suggests that employee's entrepreneurial activity may be different at various organizational-levels (Hornsby et al., 2009; Sieger, Zellweger and Aquino, 2013). Moreover, employee entrepreneurial activity may serve as a form of challenging extrarole behavior (Hughes et al., 2018; Rigtering and Weitzel, 2013) occurring outside of the employee’s job scope (Åmo and Kolvereid 2005). In line with Lau et al. (2012), de Jong et al. (2013) and Shane and Venkataraman (2000) opportunity-seeking view of entrepreneurship, we sought a behavioral-based approach to defining employees' active contribution to corporate entrepreneurship. An approach centered on opportunity-seeking behavior is appropriate given the ambiguity surrounding the nomological network of 'employee entrepreneurial behavior'. In doing so also provides a sufficient degree of freedom to ensure that specific and related behaviors are not unduly excluded from our analysis. Consequently, we define employee entrepreneurial behavior as "the extent to which employees proactively engage in the creation, introduction, and application of opportunities at work, marked by taking business-related risk" (de Jong et al., 2013).

\section{Methodology}

Review Approach

Systematic reviews are noted for their thoroughness and rigor, leading to legitimacy and the objectivity of results (Tranfield, Denyer and Smart, 2003). A systematic literature review (SLR) is used to investigate the current state of research on employee entrepreneurial behavior and its contextual determinants. Providing a holistic perspective on the common knowledge base of prior research into employee entrepreneurial behavior, SLRs can contribute to the development of the field by identifying different research streams and illustrating possible future 
research agendas. The SLR was developed using the principals and procedures outlined by Wang and Chugh (2014).

\section{Scope of Review}

In conducting our SLR, we set the following boundary conditions. Firstly, we restricted the SLR to English peer-reviewed, empirical articles published between January 1985 and December 2016. Books, book chapters or conference papers, non-English manuscripts and/or conceptual papers were excluded. Second, the SLR focused only on scholarly articles published in journals listed in the Association of Business Schools (ABS) Academic Journal Quality Guide Version 5 in the subject domains of: "Entrepreneurship and Small Business”, "Innovation”, and 'Strategic Management." We also included “Organization Studies" and "General Management", and the subject domains of "Organizational Psychology"; and "HRM" in order to capture relevant studies from these disciplines. These latter two subject areas have a long history of publishing studies attending to topics related to employee entrepreneurial behaviours such innovative work behaviour (Hughes et al., 2018; Woods et al., 2018) and personal initiative (Freese et al., 1997) and the determents of such behaviour's. Finally, we only included studies in journals listed in ABS category 2 or higher journals due to quality considerations.

\section{Review Search and Analysis Strategy}

Based on an initial review of the literature on employee entrepreneurial behavior by Lau et al. (2012) and Belousova and Gailly (2013) several closely related terms were identified as being used to describe such behavior. Some scholars have referred to employee entrepreneurial behavior simply as 'entrepreneurial behavior'' or 'Corporate Entrepreneurs'. However, other

\footnotetext{
${ }^{1}$ Due to UK and US differences in English spelling, we also searched for the different spellings of the term behavior (eg Behaviour )
} 
terms such as 'intrapreneurial' behavior' or 'intrapreneuring' have been used. Accordingly, this study decided to include both pre-fixes 'intrapreneurial' and 'entrepreneurial' in order to increase the breadth of the SLR search. Hence, we used the following keyword combinations as part of the search criteria: ("entrepreneurial behavior") OR ("intrapreneurial behavior") OR (“Entrepreneurial action*”) OR (“Intrapreneuring”) OR ('Intrapreneurial action*') AND (Intrapreneurship*) OR (Corporate Entrepreneurship*) OR ('Innovativeness') OR ('Strategic Renewal') OR ('Business/Corporate Venturing') OR ('Strategic Entrepreneurship'). The primary keywords were intentionally broad to cover as many articles as possible in the first search and to produce a significant number of articles, even if many were less relevant to the present study. All, key terms and their combinations were used to search the titles, keywords and abstracts of the following popular databases: EBSCO, ABI-Inform, Emerald, ISI-Web of Knowledge, Science Direct and Springer-Link.

The above search strategy yielded a total of 338 articles. Next, we developed a set of exclusion criteria to ensure that each of the 338 articles fell within the conceptual boundaries we set earlier. In particular, we excluded:

1. Non-empirical articles (e.g. conceptual studies) or works which are practitioner orientated. For example, the article by Kuratko et al. (2005a) was excluded because it was conceptual piece aimed at developing a model of middle-managers entrepreneurial behaviour and thus lacked empirical (qualitative/quantitative) evidence.

2. Articles that did not substantially discuss employee entrepreneurial/intrapreneurial behaviors in relation to Corporate Entrepreneurship and its contextual determinants. 
Hence, we excluded the study by Pearce, Kramer and Robbins (1997) on managers' entrepreneurial behavior as its primary focus was on the effects of such behaviour on subordinates attitudes. Hence a discussion concerning the determinants of managers' behavior was lacking. Similarly, Brundin, Patzelt and Shepherd's (2008) study was excluded, as it focused only on managers emotional displays as determinants of employee entrepreneurial behavior, and thus did not consider any contextual determinants nor have a significant discussion concerning Corporate Entrepreneurship.

3. Articles that focused on Corporate Entrepreneurs or Intrapreneurs skills/attributes (e.g. and intention to engage in intrapreneurship/CE instead of employee entrepreneurial behavior). In this particular study, we focus explicitly on employee's entrepreneurial behavior and not their intentions. Prior research has suggested that intentions may not translate into future behaviors (Van Gelderen, Kautonen and Fink, 2015). Hence, articles by Douglas and Fitzsimmons (2013) and Urbano and Turró (2013), although examining the contextual determinants of employee entrepreneurial behaviors, did so in relation to entrepreneurial intentions and not specific entrepreneurial behaviors.

After reading the abstract and titles of each paper and applying the exclusion criteria, a further 338 were removed as they did not contain a meaningful discussion of employee entrepreneurial behaviors in the context of CE or its contextual determinants. This left a total of 21 articles upon which to base our SLR. As a first step, the articles were analyzed with regard to their, publication information, terminology used, theoretical approaches and research design. In the second step, the articles underwent a detailed content analysis. Relevant issues in the articles were coded, and finally, different research subjects were identified, synthesized and in a final 
step re-organized into research streams based on the different types of contextual determinants. Table 1 provides a summary of the 21 articles and their key findings.

\section{INSERT TABLE 1 HERE}

\section{Findings}

An Overview of Employee Entrepreneurial Behavior Research

The sample of the SLR provides insight into the journals in which studies of employee entrepreneurial behavior have been published (see Table 1). The majority of studies appeared in the subject area of Entrepreneurship and Small Business Management, $(\mathrm{N}=14)$, followed by Organisation Studies $(\mathrm{N}=4)$. This is not surprising considering the field's theoretical foundations in entrepreneurship and strategic management. The journal with the most publications in the field was International Entrepreneurship and Management Journal, with eight articles in total. The period between 2008-2014 saw the highest number of studies published with a total of fifteen articles. Broadly, such findings suggest that research into employee entrepreneurial behavior remains firmly rooted in the subject areas of Entrepreneurship and Organization Studies. Also, it demonstrates that the concept remains emergent.

The SLR detected great diversity in terminology used to refer to employee entrepreneurial behavior (see Table 2). The term 'entrepreneurial behavior' emerged as the most consistently used term in the literature $(\mathrm{N}=9)$, followed by "intrapreneurial behavior' $(\mathrm{N}=3)$. Both these terms were used consistently by studies from 2010 onwards. To a lesser extent, terms such 'Corporate Entrepreneurial Actions' ( $\mathrm{N}=2)$, 'Individual Innovativeness' ( $\mathrm{N}=2)$, 'Dispersed 
Corporate Entrepreneurship' ( $\mathrm{N}=1)$; Corporate Entrepreneur/Intrapreneur $(\mathrm{N}=2)$, Corporate Entrepreneurship $(\mathrm{N}=1)$ and Bootlegging behavior $(\mathrm{N}=1)$ have also been used. However, such terms appear to be used sporadically throughout the literature and mostly before 2010.

The sample articles explored two broad streams. Majority of studies $(\mathrm{N}=18)$ focused on the theme of what encourages employee entrepreneurial behavior (e.g. Amo and Kolvereid, 2005; Hornsby et al., 2009; Rigtering and Weitzel, 2013). Regarding this research stream, studies focused specifically on individual and organizational antecedents of such behavior (eg. Amo and Kolvereid, 2005; Kuratko et al., 2005b; Rutherford and Holt, 2007; Sieger, Zellweger and Aquino, 2013; Zampetakis and Moustakis, 2007; Zampetakis, Beldekos and Moustakis, 2009). For instance, several studies focused on the role of middle-level managers, coaching and leadership styles and their influence employees' entrepreneurial self-efficacy (Moriano et al., 2014; Valsania, Moriano and Molero, 2016; Wakkee, Elfring and Monaghan, 2010). Within this stream, a total of 14 studies also tried to link the organizational and individual antecedents by developing a combined model of CE and employee entrepreneurial behaviors (eg. Åmo and Kolvereid 2005; Croonen, Brand and Huizingh, 2016; De Clercq, Castañer and Belausteguigoitia, 2011; Rutherford and Holt, 2007).

In addition to what drives employee entrepreneurial behavior, the outcomes of employee entrepreneurial behavior also emerged as an important stream of research $(\mathrm{N}=7)$. A total of 5 studies attempt to link employee entrepreneurial behavior to firm-level entrepreneurship. For instance, Brunaker and Kurvinen (2006), Heinonen and Toivonen (2008) and Belousova and Gailly (2013) showed how managers willingness to challenge the status quo and act as change agents could bring about CE. However, only two studies considered how employee entrepreneurial behavior can further stimulate pro-organizational behaviors and attitudes such as 
increased job satisfaction and commitment as well as an increased willingness to search out useful information (Park, Kim and Krishna, 2014; Rutherfold and Holt, 2007)

In addition to thematic diversity, the sample articles also adopted different methodological approaches. Most articles adopted a quantitative research design $(\mathrm{N}=19)$ with only two articles adopting qualitative research designs such as a single (Brunaker and Kurvinen, 2006,) or multiple case studies (Belousova and Gailly, 2013). Almost all studies were of crosssectional design in nature with only two applying a longitudinal design, using interviews to analyze the emergence of employee entrepreneurial behavior (Belousova and Gailly, 2013; Brunaker and Kurvinen, 2006). Majority of articles adopted a theory testing approach ( $\mathrm{N}=19)$, with little in the way of exploratory studies. Diversity was also observed with respect to the context in which the research was carried out. Four articles focused on employee entrepreneurial behavior in small to medium-sized firms (SMES) (De Jong et al., 2013; Sieger, Zellweger and Aquino, 2013; Rutherford and Holt, 2007), while three in large firms (Belousova and Kurvinen, 2013; De Clercq, Castañer and Belausteguigoitia, 2011; Wakkee, Elfring and Monaghan, 2010). A further seven studies examined employee entrepreneurial behavior among both SMEs and larger-sized-firms (Globocnik and Salomo, 2015; Moriano et al., 2014; Park, Kim and Krishna, 2014; Rigtering and Weitzel, 2013, Sebora and Theerapatvong, 2009; Valsania, Moriano and Molero, 2016). Although scholars have acknowledged that entrepreneurial process in firms can vary with respect to organizational size (Nason, McKelvie and Lumpkin, 2015), only one study (Sebora and Theerapatvong, 2009) specifically examined whether organizational size mattered.

Regarding the locus of employee entrepreneurial behavior, nine article (eg De Clercq, Castañer and Belausteguigoitia, 2011; Sebora and Theerapatvong, 2009; Wakkee, Elfring and Monaghan, 2010) focused specifically on the entrepreneurial behavior of managers (e.g. lower, 
middle or senior management), with only one article explicitly comparing entrepreneurial behaviors across different managerial-levels (Hornsby et al., 2009). Four articles focused solely on rank-and-file employees (e.g. Moriano et al., 2014; Rutherfold and Holt, 2007; Zampetakis, Beldekos and Moustakis, 2009) and a further twelve sampled both managerial and nonmanagerial employees, however we note there was no specific attempt by these articles to make a distinction between employee levels (see Table 2).

INSERT TABLE 2 HERE

\section{Theories and Perspectives on Employee Entrepreneurial Behavior}

Scholars of CE have long called for the content of such behaviors to be examined at the individual-level (Kruass et al., 2005). The analysis of the 21 reviewed articles, specifically looked at how authors have conceptualized employee entrepreneurial behavior. Evidence suggests that employee entrepreneurial behavior is a multi-dimensional higher order construct consisting of three broad dimensions; namely innovativeness, proactiveness and risk-taking. Although similar to the conceptualization of entrepreneurial orientation (Lumpkin and Dess, 1996), however, while our review broadly confirms this view, it also suggests that at the individual level, these behaviors may manifest themselves in different ways from that of CE.

As evident from Table 2, Innovativeness, emerged as the most common dimension of employee entrepreneurial behavior. Innovative employees were ones who recognized workrelated problems and generated new and novel ideas and solutions to solve them (e.g. Amo and Kolvereid, 2005; Hornsby et al., 2009, Kurtako et al., 2005b, Park, Kim and Krishna, 2014; Rutherford and Holt, 2007, Rigtering and Weitzel, 2013; Valsania, Moriano and Molero, 2016). For instance, Zampetakis and Moustakis (2007; 2010) suggested employees' innovativeness 
involves solving organizational and work issues by finding official and unofficial workarounds to such problems. Additionally, when faced with increasing competition and rapidly changing conditions, entrepreneurial employees may also propose new ideas that help to transform the organization (Croonen, Brand and Huizingh, 2016) or develop and introduce new products and services to meet increasing market demands (Sebora and Theerapatvong, 2009).

Employee proactiveness emerged as the second most important dimension of employee entrepreneurial behavior. Articles from the SLR suggest that employee proactiveness includes a range of self-initiated and future orientated actions aimed at changing and improving the organization's current situation. Studies have viewed such behavior as reflective of a strong change orientation (eg. (Belousova and Gailly, 2013; Heinonen and Toivonen, 2008), the ability to develop a new strategic vision (Zampetakis and Moustakis, 2010; 2007), employees abilities to recognize and identify entrepreneurial opportunities (de Jong et al., 2013; Moriano et al., 2014; Rigtering and Weitzel, 2013; Wakkee, Elfring and Monaghan, 2010), seeking formal and informal support from others to execute such opportunities, or supporting fellow employees entrepreneurial activity through creating entrepreneurial environments (Sieger, Zellweger and Aquino, 2013; Zampetakis and Moustakis, 2007; 2010). Broadly, the proactive behaviors of employees can be regarded as trying to improve internal organizational systems and process or the fit between the organization and its external environment.

Individual risk-taking emerged as the third most common dimension of employee entrepreneurial behavior. Individual risk-taking includes challenging the existing status quo (Heinonen and Toivonen, 2008) by boldly moving forward with initiatives (Brunaker and Kurvinen, 2006) or deliberately cutting through red tape (Zampetakis and Moustakis, 2007; 2010). Such risk-taking behaviors appear to be different from that at the firm-level which often 
involves venturing into the unknown, borrowing heavily or committing significant resources to unknown environments (Rauch et al., 2009), and may also take place without the explicit permission of management. In sum, articles in the SLR tended to view employee entrepreneurial behavior as a constellation of sub-behaviors which may be highly inter-related with each other and that have common consequences for CE. For instance, the creation of new ventures on behalf of their employer, employees' entrepreneurial behavior may also consist of a broader array of actions relating to new product development, process and administrative improvements, or work role innovations (de Jong et al., 2013) or help others to behave entrepreneurially (Sieger, Zellweger and Aquino, 2013).

Articles from SLR were found to apply various theoretical lenses to investigate employee entrepreneurial behavior. Theories of social exchange are among the most influential conceptual paradigms used for understanding workplace behavior and were highly evident throughout the SLR. Based on assumptions that relationships evolve into trusting, loyal, and mutual commitments, various articles in the SLR have used exchange theories to understand some of mechanisms by which employees entrepreneurial behavior emerges (Moriano et al., 2014 Rigtering and Weitzel, 2013; Valsania, Moriano and Molero, 2016). For instance, Zampetakis, Beldekos and Moustakis (2009) used social exchange theory to understand how employees' favourable perceptions of a supportive organizational climate may be reciprocated in the form of individual entrepreneurial actions. Additionally, Valsania, Moriano and Molero (2016) and Moriano et al. (2014) studies used exchange theories to analyse the relationships between entrepreneurial employees and management's leadership styles. In general, exchanged-based theories have tended to view employee entrepreneurial behavior as occurring when employees feel and perceive that their organization cares for their well-being and values their contribution. 
Some articles in the SLR were also found to draw on social learning theory (Bandura, 1977) to understand individual differences in employee entrepreneurial behavior. Social learning theory states that the learning of novel behavior is a cognitive process embedded in a social context and occurs through observation and imitation of others. The concept of self-efficacy and more recently entrepreneurial self-efficacy (ESE), is part of social learning theory (Bandura, 1977) and refers to an individual's perceived ability to show certain behaviors or fulfil certain tasks. Self-efficacy is influenced by skills, their application and the feedback on applying these skills. Several articles in the SLR examined either self-efficacy or entrepreneurial self-efficacy in influencing innovative and entrepreneurial behaviors (Globocnik and Salomo 2015; Rutherford and Holt, 2007; Wakkee, Elfring and Monaghan, 2010). Surprisingly, on a few articles in the SLR drew on motivation-based theories to examine motivational factors for engaging in entrepreneurial behavior. Motivators such as feelings of ownership (Sieger, Zellweger and Aquino, 2013) and specific emotional states (Rutherford and Holt, 2007) were used to understand why employees engage in entrepreneurial behavior. Additionally, De Clercq, Castañer and Belausteguigoitia (2011) and Valsania, Moriano and Molero (2016) studies drew on expectancy theory to show how the entrepreneurial behavior of managers was related to their dissatisfaction with the status quo in their respective organizations and by threat of competition from the market.

Overall, the SLR reveals a lack of over-arching theoretical frameworks and terminology used to explain employee entrepreneurial behavior. This is consistent with earlier observations by Urbano and Turro's (2013), who suggested that despite the CE field's long history in the both the Strategic Management and Entrepreneurship literatures, studies fail to draw on relevant theories. With the exception of Sieger, Zellweger and Aquino (2013) and Globocnik and Salomo 
(2015), articles in our SLR have not tended to draw upon multiple theoretical perspectives. This is surprising given that prior research has suggested that entrepreneurial behavior in organizations emerges through complex process (Rigtering and Weitzel, 2013).

\section{Contextual Determinants of Employee Entrepreneurial Behavior}

The articles in the SLR were organized into three broad categories of contextual determinants: job/role (e.g. studies which examined specific aspects of employees job/role within the organisation), work/organizational (e.g. studies which examined structures, process, support, rewards and culture of organizations) and external environment and firm characteristics (e.g. studies which examined firm type and size, national cultures, market conditions)(See Table 3). In determining the three broad contextual categories a three-stage coding process was used. Firstly, two of the authors independently coded each of the 21 articles to determine the contextual type (e.g., job, work/organizational/environmental/firm). Next, sub-codes (e.g., leadership, support, autonomy) which emerged from each of the articles were developed. Finally, the authors met together to discuss any discrepancies in their coding. In the following section, we provide an overview of our findings concerning the contextual determinants.

\section{INSERT TABLE 3 HERE}

\section{Job/role Context Determinants}

At the job/role level, the specific design and characteristics of an employee's job is often mentioned as an important antecedent of CE (Hornsby et al., 2009). The SLR identified specific 
features of employees' job/roles which can encourage them to engage in entrepreneurial behavior. Findings from the SLR point to the importance of giving employees significant decision-making latitude as a means of encouraging their entrepreneurial behavior (De Jong et al., 2013; Kuratko et al., 2005b). Such autonomy is particularly important for those employees in higher managerial positions (Hornsby et al., 2009; Zampetakis and Moustakis, 2007) and in encouraging certain aspects of entrepreneurial behavior such as proactivity (De Jong et al., 2013) and engaging in boot-legging behavior (Globocnik and Salomo, 2015).

Prior research suggests that employees need spare or free time away from core job/role tasks to successfully work on entrepreneurial ideas (Hornsby et al., 2009). Contrary to such assumptions, time availability emerged as a significant factor that curtailed employee's entrepreneurial behavior (Hornsby et al., 2009). Being under-significant time pressure may be a necessary condition to stimulate employees to look for alternative and creative means to address organizational problems cutting through red tape and thinking outside the box. However, when employees have too much free time, they may not experience the optimal levels of stress necessary to simulate innovativeness and creativity and may also lose their attentional focus. Additionally, scholars have also recognized the significance of personal knowledge, experiences and networks in driving entrepreneurial behavior (Wiklund and Shepherd, 2003). Hence, job designs which encourage horizontal exchanges and networking opportunities among employees (Rigtering and Weitzel, 2013), was found to positively influence their entrepreneurial behavior by encouraging the recognition and exploitation of new knowledge and opportunities (Belousova and Gailly, 2013).

Employees with longer tenure are expected to the have developed the necessary idiosyncratic organizational knowledge, experience and networks necessary to generate novel 
solutions to problems and implement them (Ng and Feldman, 2011). However, the SLR did not find evidence of longer tenure positively influencing employee's entrepreneurial behavior (Zampetakis, Beldekos and Moustakis, 2009). Two possible reasons may explain this finding. Firstly, an important element of entrepreneurial behavior is taking risks and opening one's self to new experiences (Rigtering and Weitzel, 2013). Longer-tenured employees may be more likelty to feel a greater sense of job security (Zampetakis and Moustakis, 2010) and complacency in the tasks they are doing. Hence, they may be less motivated to try and explore new ideas which may threaten their job security. Additionally, longer-tenured employees may experience difficulties in carrying out individual entrepreneurial activities as they may be less likely to seek out organizational support for their actions (Zampetakis, Beldekos and Moustakis, 2009).

\section{Organizational/Work Context Determinants}

Numerous studies have highlighted the significance of on an employee's organizational and work contexts and their influence on entrepreneurial behavior (e.g. Åmo and Kolvereid 2005; Rigtering and Weitzel, 2013). By focusing on structures, processes and cultures, several studies have offered insights into influential organizational characteristics that encourage and sustain employee entrepreneurial behavior. One of the most important sub-themes to emerge was the role of management support and leadership in fostering employee entrepreneurial behavior. Many of the articles in this sub-theme viewed management as enablers of employee entrepreneurial behavior. Specifically, management's positive attitudes towards innovative and entrepreneurial behaviors (Amo and Kolvereid, 2005; Park, Kim and Krishna, 2014) and their willingness to provide ongoing support (Kurtako et al., 2005b; Rutherford and Holt, 2007) was identified as raising employee's awareness and interest in entrepreneurship. Also, the role of 
managers in championing employee's initiative and acting as change agents also emerged as a source of motivation for employees entrepreneurial behavior (Heinonen and Toivonen, 2008; Kurtako et al., 2005b). For example, Belousova and Gailly (2013) showed how the promotional behavior of managers in the form of facilitating feedback, evaluation, continuous adjustment and experimentation facilitated entrepreneurial process.

Several articles also highlighted how leadership styles can create a sense of trust, empowerment and identification among employees, thereby indirectly encouraging their entrepreneurial behavior (Moriano et al., 2014; Rigtering and Weitzel, 2013; Valsania, Moriano and Molero, 2016). Transformational, as opposed to transactional leadership styles (Valsania, Moriano and Molero, 2016), was found to create a sense of empowerment and identification with the organizations among employees. This can, in turn, lead to the enhanced commitment of employees in decision-making processes and trust between management and employees (Rigtering and Weitzel, 2013). With regards to processes, various formal management processes which allow strategic autonomy (Globocnik and Salomo, 2015; Hornsby et al., 2009; Rigtering and Weitzel, 2013) and encourage open communication (Åmo and Kolvereid 2005; Heinonen and Toivonen, 2008; Park, Kim and Krishna, 2014; Zampetakis and Moustakis, 2007) were identified as relevant factors in ensuring an entrepreneurially friendly work environments (Kuratko et al., 2005b) and strengthening the commitment and participation of employees (Park, Kim and Krishna, 2014; Valsania, Moriano and Molero, 2016). Formalization of systems and process further ensures that resources, such as finances and coaching and training activities (Wakkee, Elfring and Monaghan, 2010; Zampetakis and Moustakis, 2007) are made available and distributed accordingly to support employee entrepreneurial behaviors (Kurtako et al., 2005b; Hornsby et al., 2009; Rigtering and Weitzel, 2013; Rutherford and Holt, 2007). 
In addition to providing support for employee entrepreneurial behavior, ensuring that such is appropriately recognized and rewarded is another way which organizations and management can signal their support for such behavior (Hornsby et al., 2009; Sebora and Theerapatvong, 2009). Accordingly, articles from the SLR suggest that rewards are an important determinant of employee's entrepreneurial behavior. However, findings also point out that in addition to monetary rewards (Rutherford and Holt, 2007), non-monetary rewards such as training, career development opportunities can also act as significant enablers of employee entrepreneurial behavior.

In addition to the factors presented above, a strong underlying sub-theme was culture. Entrepreneurially friendly work environments can help create physical nearness and stimulates various aspects of cooperation, as well as a reduced hierarchy and bureaucracy to ensure knowledge sharing and joint idea generation (Park, Kim and Krishna, 2014; Rigtering and Weitzel, 2013). Furthermore, internal environments highly conducive to entrepreneurship (Sebora and Theeraptvong, 2009) signal management's commitment to entrepreneurship as a strategy (Amo and Kolvereid, 2005) and provides an opportunity for employees to 'step up to the plate'. Hence, employees who perceive that their organizational cultures are supportive of their entrepreneurial activity (Sebora and Theeraptvong, 2010; Zampetakis, Beldekos and Moustakis, 2009; Zampetakis and Moustakis, 2007) have been found to be more willing and proactive in acting on their entrepreneurial potential

\section{External Environment Context and Firm Characteristics Determinants}


Prior research has suggested that the external environment, as well as organizational type and size, can condition employees towards entrepreneurial activity (Urbano and Turró, 2013). The SLR identified specific firm characteristics such as type and size and perceptions of market competitiveness as further determinants of employee entrepreneurial behavior. Regarding firm characteristics, being a manufacturing and a larger firm was found to significantly influence managers' willingness to take risks concerning entrepreneurial opportunities (Sebora and Theerapatvong, 2009). This might be attributed to the fact that larger firms may not only better reward employees for their entrepreneurial behavior, but they may also be better positioned to absorb the risks associated with employees entrepreneurial activities as they typically have larger resource endowments. Additionally, because of the hyper nature of competition, manufacturing firms might need to be at the forefront of adopting and developing innovations in order to remain competitive.

Only two articles accounted for the external environments effects on employee's entrepreneurial behavior (Croonen, Brand and Huizingh, 2016; Sebora and Theerapatvong, 2009). Specifically, these articles showed that employees and managers perceptions of the extent of local competition can encourage managers to engage in specific entrepreneurial behaviors (Croonen, Brand and Huizingh, 2016; Sebora and Theerapatvong, 2009). For instance, Sebora and Theerapatvong (2009) found that manager's knowledge concerning local competition and operating environments increased their willingness to take risks and be innovative. Similarly, Croonen, Brand and Huizingh (2016) showed that franchisee owners were likely to respond to intense local competition by being innovative and introducing strategic renewal into their enterprise. In sum, the SLR findings suggest that employees and managers in large and manufacturing firms may be encouraged to engage in entrepreneurial behavior in order to 
counter the possible adverse effects of such firms operating in highly dynamic and competitive markets.

\section{Discussion}

The purpose of this study was to systematically examine extant research into employee entrepreneurial behavior and identify its contextual determinants. The tendency of corporate entrepreneurship studies to overlook individual behaviour in favour of organizational design instruments and conditions has left managers with a puzzling problem: how to change the behavior of employees to enable and sustain entrepreneurship and innovation? The answer lies in catalysing employee entrepreneurial behavior.

Our SLR provides a map of the state of current research and knowledge on employee entrepreneurial behavior, its features, emerging nomological network, and its susceptibility to context. The SLR reiterates the need for scholars to properly differentiate between entrepreneurial behaviors at the firm level and those at the individual level. A sizable concern is that firm-level entrepreneurial behavior originates from the entrepreneurial orientation of the organization, itself set in place by senior managers and reflective of their decision-making processes and practices that are entrepreneurial in nature (Covin and Slevin, 1989; Hughes and Morgan, 2007; Lumpkin and Dess, 1996). This is made more problematic by recent characterisations of entrepreneurial orientation as representing attitude (risk-taking) and behaviour (proactiveness and innovativeness) (Anderson et al., 2015). This suggests that employee entrepreneurial behavior may mirror some of these characteristics with the right management (e.g., proactivity and a willingness to take individual risks). But our review also suggests it will exhibit its own unique characteristics commensurate with a view of entrepreneurship at the individual-level (e.g., idea generation). Current studies of employee 
entrepreneurial behavior, however, clearly indicate an affinity to associate individual employee entrepreneurial behavior with entrepreneurial orientation. That association in defining its characteristics is very likely to miss or omit a broader series of behaviors unique to the individual employee level and neglect the complexities of specific types of behavior (e.g., those related to innovation alone; see Hughes et al., 2018).

For employee entrepreneurial behavior, an analysis of its core dimensions suggests that such behavior manifests itself in quite different ways from those at the firm-level. For example innovativeness at the firm-level involves the redesigning of existing business models or the commercialization of new ideas. Yet, at the individual level, innovativeness may involve an employee's proactive efforts in identifying market opportunities and in proposing new ideas to help solve existing work/organizational-related problems. Similarly, the ability of the organization to discover and exploit opportunities may be highly dependent on an employee's willingness to introduce new ideas and innovations into the organization by taking personal risks to bypass authority and act independently. Concurrently, that willingness, and subsequent ability to act, is conditioned by contextual factors. Hence, the SLR findings reinforce earlier observations by De Jong et al. (2013) and Lau et al. (2012) that employee entrepreneurial behaviors may actually inform CE. Nonetheless, more research is needed to understand and identify the unique aspects of employee entrepreneurial behavior and how they inform both team and CE and the conditions which enable or restrict (or demotivate) action.

The SLR identifies three broad clusters of contextual determinants of employee entrepreneurial behavior: (1) the employee's job/role context; (2) the organizational/work context; and (3) the union of firm characteristics and the external environment context. Figure 1 summarizes these contextual determinants into a conceptual model of the nomological network 
of employee entrepreneurial behaviour. The, solid lines represent our current knowledge regarding the empirical evidence concerning the contextual determinants of employee entrepreneurial behaviour, while the dotted boxes and lines emphasize areas for which future research is needed.

\section{INSERT FIGURE 1 HERE}

Contingency theory thinking (Boyd et al., 2012; Burns and Stalker, 1961; Lawrence and Lorsch, 1967) tends to lead scholars to focus their attention on the union of firm characteristics (including organizational design) and the external environment (including industry), the third overall context in Figure 1. However, a more granular focus on micro and meso contexts at the level of the individual's role and their work context is necessary. Our SLR suggests they bear effects either directly on employee entrepreneurial behavior, or indirectly by affecting the antecedent conditions that stimulate employee entrepreneurial behavior. This difference is essential to the management puzzle at the heart of this paper: why individual employees may not adopt or exhibit entrepreneurial behaviors despite the organizational design efforts of senior managers. Our conceptual model (Figure 1) synthesis of the findings from the SLR highlights that the job/role context and work/organizational context has a direct bearing on each other as well as on the entrepreneurial culture of the firm. Together, these contribute to proentrepreneurship architecture within the organization (e.g., Ireland et al., 2009).

How such conditions, together with actions taken to devise a corporate entrepreneurial environment change, shape and set employee behavior generally remains a black box, however. From our SLR, it is apparent that a fundamental answer to this problem derives from understanding the various contexts in which employee entrepreneurial behavior takes place. Based on content analysis of the relevant articles, and the model developed in Figure 1, 
organizations and managers play an influential role in shaping employees entrepreneurial activity by developing and sustaining entrepreneurially-friendly structures and process. Specifically, management's commitment to an entrepreneurial strategy and philosophy, ensuring availability of financial and non-financial resources, appropriately designing and structuring jobs to enhance networking, recognizing and rewarding entrepreneurial efforts emerged as significant organizational/work and job/role related enablers of employee entrepreneurial behavior. The outcome of developing such structures and processes is the creation of organization-wide entrepreneurial culture. Such cultures serve as an important conduit to encourage the development of entrepreneurial skills and "extra-role" behaviors, by encouraging employees to experiment with new ideas and initiatives via trial-and-error and to challenge established organizational norms. Additionally, employee perceptions and reactions to the munificence or threats contained in their external environments (Hughes and Mustafa, 2017), can further catalyze entrepreneurial behavior and shape entrepreneurial cultures. Central to debate is the need for a sharper understanding of the actions and leadership of middle-managers as a conduit between senior management (who, according to theory, set the entrepreneurial orientation of the organization) and employee entrepreneurial behavior by individuals dispersed across the organization and its hierarchy.

Finally, our analysis of the SLR presented in Figure 1 suggests that in addition to job and work context, more needs to be known about the individual characteristics of those employees that both exhibit and seemingly do not exhibit entrepreneurial behavior. A particular emphasis on employee entrepreneurial self-efficacy, psychological ownership in the role and of the organization, as well as emotional intelligence and other demographics like age and gender is warranted. The study of employee entrepreneurial behavior cannot be divorced from the study of 
properties pertaining directly to these individuals themselves. However, care is needed to mitigate a bias originating from studying only those that exhibit entrepreneurial behavior because a failure to exhibit such behavior can also be due to context as summarised in Figure 1, and not due to the strict presence or absence of individual properties that may facilitate entrepreneurial behaviors in other situations. Many studies of corporate entrepreneurship, entrepreneurial orientation and employee entrepreneurial behavior are guilty of, or susceptible to, this bias. Given our SLR draws attention to the importance of context, a false consensus may be reached if we ignore the individual properties of employees both within and outside these contextual conditions to unlock the puzzle of why entrepreneurial behavior may not occur despite a seemingly positive internal organizational environment for entrepreneurship.

\section{Limitations and Suggestions for Future Research}

While the SLR provided some interesting findings concerning the contextual determinants of employee entrepreneurial behavior, it also has several limitations which require further attention. One limitation of the study is that we only uncovered a general set of entrepreneurial behaviors and thus may not be representative of all employee entrepreneurial activity or behaviors. Hence, to deepen our understanding of entrepreneurship within firms and employee entrepreneurial behaviors as its antecedent, more effort at properly conceptualizing and defining employee entrepreneurial behavior is needed. Current approaches to conceptualization of employee entrepreneurial behavior have been largely informed by the firmlevel construct of entrepreneurial orientation. Such approaches have made it difficult to distinguish such behaviors from that of firm-level entrepreneurial behavior. Given the different levels of analysis involved, it is plausible that the individual entrepreneurial behavior of employees can aggregate into firm level activities, rather than mirror it. This logic is consistent 
with a microfoundations view of how organizational activities emerge (e.g., Foss and Pedersen, 2016). Thus, future research is needed to explore the uniqueness of employee entrepreneurial behavior, via a closer examination of its core components. Particularly fruitful here may be the adoption of explorative methods, such as interviews, case studies and/or critical incident techniques which may uncover the unique aspects of such behavior. Future research here may also consider the entrepreneurial behaviors and qualities associated with successful (or failed) entrepreneurs and intrapreneurs, and ask how these are translated within organizations, whereby many groups of employees work together to produce the same outcome that one person might during new venture creation. Equally worthwhile would be to study effects of current and historical leaders or senior managers on employee's favor or reluctance towards entrepreneurial behavior.

Extant definitions of employee entrepreneurial behavior (e.g., by Lau et al., 2012, and de Jong et al., 2013) continue to be based around the broader definitions of entrepreneurship and the notions of opportunity recognition and opportunity exploitation (Shane and Venkataraman, 2000). To some extent, this is commensurate with the idea of opportunity-seeking behavior being at the heart of corporate entrepreneurship strategy (e.g., Ireland et al., 2009) and strategic entrepreneurship (Ireland, Hitt and Sirmon, 2003). However, we recognize that the lack of precise definition of the concept has not only led to difficulties in identifying and measuring the concept, but has also decelerated the development of its definition. By extension, this has decelerated investigation into the nomological network of employee entrepreneurial behavior and the manner in which employees can be actively involved in corporate entrepreneurship. We urge future researchers to strive towards addressing such issues and bring additional definitional and conceptual clarity to employee entrepreneurial behvaior. 
Second, we need to acknowledge that the model presented in Figure 1 may be incomplete and may benefit from further refinement. Specifically, there could be other factors or features of context which could also affect employee entrepreneurial behavior, but might not have emerged as part of SLR. For example, prior research has acknowledged that entrepreneurial behavior in organizations emerges through complex process (Rigtering and Weitzel, 2013). However, findings from the SLR showed few articles to take into consideration the complexities associated with the different levels and types of context and more specifically their interactions. Similarly, recent studies of corporate entrepreneurship in national cultures that are not predominantly Western in their characteristics suggest that the conditions for corporate entrepreneurship can vary substantially form expectations set in the literature (e.g., Hughes and Mustafa, 2017). Additionally, both the job role of the employee and the nature of the organization in which they are employed in (eg high tech vs no tech, large vs small, profit vs non-profit) may also influence employees entrepreneurial behavior. Hence, we urge future researchers to consider more fully the complexities associated with context, by considering the possible interactions between the job/role, organizational/work and broader dimensions of external contexts that those given treatment to date. For example, the manner in which an employee' job/role is designed can inform their perceptions of the organizational/work contexts as well as their perceptions of the entrepreneurial culture but their actions may then be conditioned by other national culture dimensions. Also, managers' leadership styles and willingness to support employees' entrepreneurial behaviors may be heavily influenced by the firm context, such as firm's size and type as well as their perceptions of the external environment, but also by features of a national culture. 
Third, the model presented in Figure 1 may not fully capture how the different types of context identified are linked together. Thus, future research may also wish to consider how the various types of context identified in the SLR are linked together. Particularly worthwhile here may be considerations around the role of management in linking the various contexts. Research has long acknowledged the influencing role of middle-level managers as bridging actors (Belousova and Gailly, 2013; Hornsby et al., 2009) due to their closeness to employees but also top management. In such roles, middle-managers can act as enablers and stimulators of employee entrepreneurial behaviors. For instance, through providing access to resources, coaching and mentoring of talented employees (Wakkee, Elfring and Monaghan, 2010) and/or acting as network nodes between various actors/divisions/teams, middle-managers can encourage employee entrepreneurial behavior by linking together an employee's job/role and organizational/work contexts. Yet, prior research has largely been pre-occupied with exploring the supporting role of managers concerning employee entrepreneurial behavior, with scant attention paid to the stimulating role of management. Hence future research needs to explore the roles of management as both enablers and impulse generators employees' entrepreneurial behavior. Accordingly, advanced quantitative methods such as multi-level modeling and qualitative methods such case studies provide an important means through which to capture and explain such interactions (Belousova and Gailly, 2013; Moriano et al., 2014; Valsania, Moriano and Molero, 2016).

\section{Conclusion}

Employee entrepreneurial behavior remains an emergent field for researchers and one that is also of growing significance to managers and organizations wishing to promote 
entrepreneurship. Employees entrepreneurial activity has long been considered as the foundation of CE (Guerrero and Peña-Legazkue 2013; Ireland, Covin and Kuratko, 2009). However, to date scant attention has been paid in the existing literature to how context influences employee's entrepreneurial behavior (Ireland, Covin and Kuratko, 2009). In trying to address this gap in the research, this particular study utilized a systematic review of employee entrepreneurial behavior literature to understand the current state of research, its contextual determinants and the identification of interesting gaps worthy of future research. In conducting the SLR, we add to the existing literature in several ways. Firstly, our SLR represents one of the first attempts in the field to provide an overview of employee entrepreneurial behavior research. Specifically, our SLR demonstrates that employee entrepreneurial behaviors can and should be distinguished from firm-level entrepreneurial behaviors. In doing so, we are not only able to identify the distinct position of employee entrepreneurial behavior as an individual-level concept in the broader field of CE research, but also provide a knowledge base for future research to build on.

Secondly, the study contributes to the existing research on the determinants of employee entrepreneurial behavior by identifying the different contextual determinants of such behavior (Arnz, 2017). Our SLR demonstrates how contexts influence on employee entrepreneurial behavior can exist across various levels (job/role, work/organizational, firm and external). More importantly, our review of articles suggests that the determinants of employee entrepreneurial behavior can have differential effects on such behavior depending on the contextual level. In doing so, we provide a fine-grained understanding of how different levels/types of context can influence employee entrepreneurial behavior. Finally, we build on the earlier work of Arz (2017) and Hornsby, Kuratko and Zahra (2002) and highlight the importance of organizational cultures in promoting entrepreneurial activity. Specifically, the SLR highlighted the complex interactions 
that may exist between the work/role context, organizational context and middle-managers actions in creating and sustaining employee entrepreneurial behaviors. This may help researchers disentangle the reasons why employees might or might not engage in entrepreneurial behavior, even when there is a pro-entrepreneurship architecture in place.

The findings from the SLR are also of high relevance for managers and organizations alike. Top management's vision of innovativeness and employees' entrepreneurial initiatives are crucial aspects in firms realizing entrepreneurial process. Accordingly, organizational factors such as strategic autonomy, coaching of entrepreneurial employees and ensuring the availability and access to critical resources remain crucial. Equally important is the development of an entrepreneurial culture and management's clear commitment to an entrepreneurial strategy (Ireland, Covin and Kuratko, 2009). This may require managers and organizations to carefully consider how they design employee's job/roles to develop organizational cultures which encourage proactivity and ideation.

Additionally, senior management need to be particularly cognizant of middle-managers roles in creating and sustaining employee's entrepreneurial behavior. Middle-level managers are key in combining the perceptions of top management and the entrepreneurial activities of employees (Hornsby et al., 2009). Hence, instead of their "bridging role”, organizations must explore new ways in which to encourage middle-managers to get involved in entrepreneurial initiatives. Additionally, research has shown managers leadership styles to have an influential role in supporting employee’s entrepreneurial behavior (Moriano et al., 2014; Valsania, Moriano and Molero, 2016). Hence managers should be encouraged to serve as role models in encouraging their subordinates to realize ideas and seize upon opportunities. Finally, in increasing the perceived ability of employees to engage in entrepreneurial behavior, receiving 
feedback and providing learning and development opportunities is extremely important. The reciprocal connection between recognizing business opportunities, behaving entrepreneurially and receiving feedback affords an increase in the self-efficacy of employees. Organizations should therefore provide possibilities for learning and developing employee entrepreneurial skills and competencies through structured training and simulations. Such approaches may help employees gain the necessary entrepreneurial experience within the safe setting, while also developing their skills and abilities.

\section{References}

Abrell, T. and Karjalainen, T.M. (2017). The Early Stage of Internal Corporate Venturing: Entrepreneurial Activities in a Large Manufacturing Company. Journal of enterprising culture, 25(01): 1-30.

Åmo, B.W. and Kolvereid, L. (2005). Organizational strategy, individual personality and innovation behavior. Journal of Enterprising Culture, 13(01): 7-19.

Antoncic, B. and Hisrich, R.D. (2003). Clarifying the intrapreneurship concept. Journal of small business and enterprise development, 10(1): 7-24.

Arz, C. (2017). Mechanisms of Organizational Culture for Fostering Corporate Entrepreneurship: A Systematic Review and Research Agenda. Journal of enterprising culture, 25(04): 361-409.

Audretsch, D. (2012). Entrepreneurship research. Management Decision, 50(5): 755-764. Birch, D.L. (1981). Who creates jobs?. The public interest, (65), p.3.

Bandura, A. (1977). Self-efficacy: toward a unifying theory of behavioral change. Psychological Review, 84(2): 191.

Belousova, O. and Gailly, B. (2013). Corporate entrepreneurship in a dispersed setting: actors, behaviors, and process. International entrepreneurship and management journal, 9(3): 361-377

Bjørnskov, C. and Foss, N. (2013). How strategic entrepreneurship and the institutional context drive economic growth. Strategic Entrepreneurship Journal, 7(1): 50-69.

Boyd, B.K., Haynes, K.T., Hitt, M.A., Bergh, D.D., and Ketchen Jr, D.J. (2012). Contingency Hypotheses in Strategic Management Research: Use, Disuse, or Misuse? Journal of Management, 38: 278-313 
Brunåker, S. and Kurvinen, J. (2006). Intrapreneurship, local initiatives in organizational change processes. Leadership \& Organization Development Journal, 27(2): 118-132.

Brundin, E., Patzelt, H. and Shepherd, D.A. (2008). Managers' emotional displays and employees' willingness to act entrepreneurially. Journal of Business Venturing, 23(2): 221-243.

Burns, T., and Stalker, G. (1961). The management of innovation. London: Tavistock.

Busenitz, L.W., West III, G.P., Shepherd, D., Nelson, T., Chandler, G.N. and Zacharakis, A. (2003). Entrepreneurship research in emergence: Past trends and future directions. Journal of Management, 29(3): 285-308.

Camelo-Ordaz, C., Fernández-Alles, M., Ruiz-Navarro, J. and Sousa-Ginel, E. (2012). The intrapreneur and innovation in creative firms. International Small Business Journal, 30(5): 513535.

Croonen, E.P., Brand, M.J. and Huizingh, E.K. (2016). To be entrepreneurial, or not to be entrepreneurial? Explaining differences in franchisee entrepreneurial behavior within a franchise system. International Entrepreneurship and Management Journal, 12(2): 531-553.

Covin, J.G. and Slevin, D.P. (1989). Strategic management of small firms in hostile and benign environments. Strategic management journal, 10(1): 75-87.

Covin, J.G. and Miles, M.P. (1999). Corporate entrepreneurship and the pursuit of competitive advantage. Entrepreneurship theory and practice, 23(3): 47-63.

De Clercq, D., Castañer, X. and Belausteguigoitia, I. (2011). Entrepreneurial initiative selling within organizations: Towards a more comprehensive motivational framework. Journal of Management Studies, 48(6): 1269-1290.

De Jong, J. and Wennekers, S., 2008. Conceptualizing entrepreneurial employee behaviour. EIM-SCALES (Scientific Analysis of Entrepreneurship and SMEs).

De Jong, J.P., Parker, S.K., Wennekers, S. and Wu, C.H. (2015). Entrepreneurial behavior in organizations: Does job design matter?. Entrepreneurship Theory and Practice, 39(4): 981-995.

Douglas, E.J. and Fitzsimmons, J.R. (2013). Intrapreneurial intentions versus entrepreneurial intentions: distinct constructs with different antecedents. Small Business Economics, 41(1): 115132.

Floyd, S.W. and Wooldridge, B., 2000. Building strategy from the middle. Sage Publications.

Foss, N.J. and Pedersen, T. (2016). Microfoundations in strategy research. Strategic Management Journal, 37(13): E22-E34.

Frese, M., Fay, D., Hilburger, T., Leng, K. and Tag, A. (1997). The concept of personal initiative: Operationalization, reliability and validity in two German samples. Journal of occupational and organizational psychology, 70(2): 39-161.

Globocnik, D. and Salomo, S. (2015). Do formal management practices impact the emergence of bootlegging behavior?. Journal of Product Innovation Management, 32(4): 505-521. 
Guerrero, M. and Peña-Legazkue, I. (2013). The effect of intrapreneurial experience on corporate venturing: Evidence from developed economies. International Entrepreneurship and Management Journal, 9(3): 397-416.

Heinonen, J. and Toivonen, J. (2008). Corporate entrepreneurs or silent followers?. Leadership \& Organization Development Journal, 29(7): 583-599.

Hornsby, J.S., Kuratko, D.F. and Zahra, S.A. (2002). Middle managers' perception of the internal environment for corporate entrepreneurship: assessing a measurement scale. Journal of Business Venturing, 17(3): 253-273.

Hornsby, J.S., Kuratko, D.F., Shepherd, D.A. and Bott, J.P. (2009). Managers' corporate entrepreneurial actions: Examining perception and position. Journal of Business Venturing, 24(3): 236-247.

Hughes, M. and Morgan, R.E. (2007). Deconstructing the relationship between entrepreneurial orientation and business performance at the embryonic stage of firm growth. Industrial marketing management, 36(5): 651-661.

Hughes, M. and Mustafa, M. (2017). Antecedents of corporate entrepreneurship in SMEs: Evidence from an emerging economy. Journal of Small Business Management, 55(S1): 115-140.

Hughes, M., Rigtering, C., Covin, J., Kraus, S. and Bouncken, R. (2018). Innovative behaviour, trust and perceived workplace performance. British Journal of Management. DOI 10.1111/14678551.12305.

Ireland, R.D., Covin, J.G. and Kuratko, D.F. (2009). Conceptualizing corporate entrepreneurship strategy. Entrepreneurship Theory and Practice, 33(1): 19-46.

Ireland, R.D., Hitt, M.A. and Sirmon, D.G. (2003). A model of strategic entrepreneurship: The construct and its dimensions. Journal of Management, 29(6): 963-989.

King, A.W., Fowler, S.W. and Zeithaml, C.P. (2001). Managing organizational competencies for competitive advantage: The middle-management edge. Academy of Management Executive, 15(2): 95-106.

Krauss, S.I., Frese, M., Friedrich, C. and Unger, J.M. (2005). Entrepreneurial orientation: A psychological model of success among southern African small business owners. European Journal of Work and Organizational Psychology, 14(3): 315-344.

Kraus, S., Rigtering, J.C., Hughes, M. and Hosman, V. (2012). Entrepreneurial orientation and the business performance of SMEs: a quantitative study from the Netherlands. Review of Managerial Science, 6(2): 161-182.

Kuratko, D.F., Ireland, R.D., Covin, J.G. and Hornsby, J.S. (2005a). A Model of Middle-Level Managers’ Entrepreneurial Behavior. Entrepreneurship Theory and Practice, 29(6): 699-716.

Kuratko, D.F., Hornsby, J.S. and Bishop, J.W. (2005b). Managers' corporate entrepreneurial actions and job satisfaction. The International Entrepreneurship and Management Journal, 1(3): 275-291. 
Kuratko, D.F. and Audretsch, D.B. (2013). Clarifying the domains of corporate entrepreneurship. International Entrepreneurship and Management Journal, 9(3): 323-335.

Kuratko, D.F., Hornsby, J.S. and Hayton, J. (2015). Corporate entrepreneurship: the innovative challenge for a new global economic reality. Small Business Economics, 45(2): 245-253.

Lau, T.L., Shaffer, M.A., Fai Chan, K. and Wing Yan Man, T. (2012). The entrepreneurial behaviour inventory: A simulated incident method to assess corporate entrepreneurship. International Journal of Entrepreneurial Behavior \& Research, 18(6): 673696.

Lawrence, P. R., and Lorsch, J. W. (1967). Organizations and environment. Boston: Harvard University Graduate School of Business Administration.

Lumpkin, G.T. and Dess, G.G. (1996). Clarifying the entrepreneurial orientation construct and linking it to performance. Academy of Management Review, 21(1): 135-172.

Miller, D. and Friesen, P.H. (1983). Strategy-making and environment: the third link. Strategic management journal, 4(3): 221-235.

Monsen, E. and Boss, R. W. (2009). The impact of strategic entrepreneurship inside the organization: Examining job stress and employee retention. Entrepreneurship Theory and Practice, 33(1): 71-104.

Moriano, J.A., Molero, F., Topa, G. and Mangin, J.P.L. (2014). The influence of transformational leadership and organizational identification on intrapreneurship. International Entrepreneurship and Management Journal, 10(1): 103-119.

Mustafa, M., Martin, L. and Hughes, M. (2016). Psychological ownership, job satisfaction, and middle manager entrepreneurial behavior. Journal of Leadership \& Organizational Studies, 23(3): 272-287.

Narayanan, V.K., Yang, Y. and Zahra, S.A. (2009). Corporate venturing and value creation: A review and proposed framework. Research Policy, 38(1): 58-76.

Nason, R.S., McKelvie, A. and Lumpkin, G.T. (2015). The role of organizational size in the heterogeneous nature of corporate entrepreneurship. Small Business Economics, 45(2): 279-304.

Ng, T.W. and Feldman, D.C. (2013). A meta-analysis of the relationships of age and tenure with innovation-related behaviour. Journal of occupational and organizational psychology, 86(4): 585-616.

Park, S.H., Kim, J.N. and Krishna, A. (2014). Bottom-up building of an innovative organization: Motivating employee intrapreneurship and scouting and their strategic value. Management communication quarterly, 28(4): 531-560.

Pearce II, J.A., Kramer, T.R. and Robbins, D.K. (1997). Effects of managers' entrepreneurial behavior on subordinates. Journal of Business Venturing, 12(2): 147-160.

Rauch, A., Wiklund, J., Lumpkin, G.T. and Frese, M. (2009). Entrepreneurial orientation and business performance: An assessment of past research and suggestions for the future. Entrepreneurship theory and practice, 33(3): 761-787. 
Rigtering, J.P.C. and Weitzel, U. (2013). Work context and employee behaviour as antecedents for intrapreneurship. International Entrepreneurship and Management Journal, 9(3): 337-360.

Rutherford, M.W. and Holt, D.T. (2007). Corporate entrepreneurship: An empirical look at the innovativeness dimension and its antecedents. Journal of Organizational Change Management, 20(3): 429-446.

Sharma, P. and Chrisman, J.J. (1999). Toward a reconciliation of the definitional issues in the field of corporate entrepreneurship. Entrepreneurship Theory \& Practice, 23(2): 1127.

Sebora, T.C. and Theerapatvong, T. (2010). Corporate entrepreneurship: A test of external and internal influences on managers' idea generation, risk taking, and proactiveness. International Entrepreneurship and Management Journal, 6(3): 331-350.

Shane, S. and Venkataraman, S. (2000). The promise of entrepreneurship as a field of research. Academy of management review, 25(1): 217-226.

Sharma, P. and Chrisman, S.J.J. (2007). Toward a reconciliation of the definitional issues in the field of corporate entrepreneurship. In Entrepreneurship (pp. 83-103). Springer, Berlin, Heidelberg.

Sieger, P., Zellweger, T. and Aquino, K. (2013). Turning agents into psychological principals: aligning interests of non-owners through psychological ownership. Journal of Management Studies, 50(3): 361-388.

Tranfield, D., Denyer, D and Smart, P. (2003). Towards a methodology for developing evidenceinformed management knowledge by means of systematic review. British journal of management, 14(3): 207-222.

Urbano, D. and Turró, A. (2013). Conditioning factors for corporate entrepreneurship: an in (ex) ternal approach. International entrepreneurship and management journal, 9(3): 379-396.

Valsania, S.E., Moriano, J.A. and Molero, F. (2016). Authentic leadership and intrapreneurial behavior: cross-level analysis of the mediator effect of organizational identification and empowerment. International Entrepreneurship and Management Journal, 12(1): 131-152.

Van Gelderen, M., Kautonen, T. and Fink, M. (2015). From entrepreneurial intentions to actions: Self-control and action-related doubt, fear, and aversion. Journal of Business Venturing, 30(5): 655-673.

Wakkee, I., Elfring, T. and Monaghan, S. (2010). Creating entrepreneurial employees in traditional service sectors. International Entrepreneurship and Management Journal, 6(1): 1-21.

Wales, W., Monsen, E. and McKelvie, A. (2011). The organizational pervasiveness of entrepreneurial orientation. Entrepreneurship Theory and Practice, 35(5): 895-923.

Wales, W.J. (2016). Entrepreneurial orientation: A review and synthesis of promising research directions. International Small Business Journal, 34(1): 3-15.

Wang, C.L. and Chugh, H. (2014). Entrepreneurial learning: past research and future challenges. International Journal of Management Reviews, 16(1): 24-61. 
Wiklund, J., Davidsson, P., Audretsch, D.B. and Karlsson, C. (2011). The future of entrepreneurship research. Entrepreneurship Theory and Practice, 35(1): 1-9.

Woods, S.A., Mustafa, M.J., Anderson, N. and Sayer, B. (2018). Innovative work behavior and personality traits: Examining the moderating effects of organizational tenure. Journal of Managerial Psychology, 33(1): 29-42.

Zahra, S.A. and Wright, M. (2011). Entrepreneurship's next act. The Academy of Management Perspectives, 25(4): 67-83.

Wiklund, J. and Shepherd, D. (2003). Knowledge-ased resources, entrepreneurial orientation, and the performance of small and medium-sized businesses. Strategic management journal, 24(13): 1307-1314.

Zampetakis, L.A. and Moustakis, V. (2007). Entrepreneurial behaviour in the Greek public sector. International Journal of Entrepreneurial Behavior \& Research, 13(1): 19-38.

Zampetakis, L.A. and Moustakis, V.S., (2010). An exploratory research on the factors stimulating corporate entrepreneurship in the Greek public sector. International Journal of Manpower, 31(8): 871-887.

Zampetakis, L.A., Beldekos, P. and Moustakis, V.S. (2009). “Day-to-day” entrepreneurship within organisations: The role of trait Emotional Intelligence and Perceived Organisational Support. European Management Journal, 27(3): 165-175. 


\begin{tabular}{|c|c|c|c|c|}
\hline Authors & Journal & Focus/Theme & Key Research Question & Key Findings \\
\hline $\begin{array}{l}\text { Amo and } \\
\text { Kolvereid } \\
\text { (2005) }\end{array}$ & $\begin{array}{l}\text { J. Enterprising } \\
\text { Culture }\end{array}$ & $\begin{array}{l}\text { Organizational and Individual } \\
\text { drivers }\end{array}$ & $\begin{array}{l}\text { What factors cause variation in the } \\
\text { innovation behaviour of employees } \\
\text { in organizations }\end{array}$ & $\begin{array}{l}\text { Employees are likely to engage in innovative } \\
\text { behaviour when they have an intrapreneurial } \\
\text { personality and there is a firm entrepreneurship } \\
\text { strategy in place. }\end{array}$ \\
\hline $\begin{array}{l}\text { Belousova and } \\
\text { Gailly (2013) }\end{array}$ & $\begin{array}{l}\text { Int. Ent. and } \\
\text { Mgnt J. }\end{array}$ & $\begin{array}{l}\text { Employee and manager } \\
\text { behavior }\end{array}$ & $\begin{array}{l}\text { How do managers contribute to } \\
\text { firm-level entrepreneurs and how } \\
\text { does their contributions change over } \\
\text { time }\end{array}$ & $\begin{array}{l}\text { Entrepreneurial projects are multi-staged process } \\
\text { which requires managerial efforts directed at co- } \\
\text { creation. Project success is determined by the } \\
\text { achievement of consensus or socially constructed } \\
\text { goals which evolve with the project }\end{array}$ \\
\hline $\begin{array}{l}\text { Brunaker and } \\
\text { Kurvinen } \\
\text { (2006) }\end{array}$ & $\begin{array}{l}\text { Leadership and } \\
\text { Org } \\
\text { Development } \mathrm{J}\end{array}$ & $\begin{array}{l}\text { Employee and manager } \\
\text { behavior }\end{array}$ & $\begin{array}{l}\text { How middle managers drive } \\
\text { organisational change through } \\
\text { developing ideas. }\end{array}$ & $\begin{array}{l}\text { Intrapreneurs are not only change agents but self- } \\
\text { appointed actors who initiates and drives process } \\
\text { of interperting events. The intrapreneurs role is } \\
\text { proactive. }\end{array}$ \\
\hline $\begin{array}{l}\text { Croonen et al. } \\
\text { (2016) }\end{array}$ & $\begin{array}{l}\text { Int. Ent. and } \\
\text { Mgnt J. }\end{array}$ & External and individual drivers & $\begin{array}{l}\text { How and why do franchisee owners } \\
\text { vary in their entrepreneurial } \\
\text { behaviour }\end{array}$ & $\begin{array}{l}\text { Franchisee owners intrinsic goals, satisfaction } \\
\text { with clients and head office as well as their } \\
\text { perception of the extent of local competition can } \\
\text { cause variations in their entrepreneurial } \\
\text { behaviour }\end{array}$ \\
\hline $\begin{array}{l}\text { De Clerq et al } \\
\text { (2011) }\end{array}$ & J. Mgnt Studies & $\begin{array}{l}\text { Organizational and Individual } \\
\text { drivers }\end{array}$ & $\begin{array}{l}\text { What factors motivate an individual } \\
\text { to sell entrepreneurial initiatives to } \\
\text { organizational members }\end{array}$ & $\begin{array}{l}\text { The characteristics of an initiative (eg its } \\
\text { potential organisational benefits and consistency } \\
\text { with current practices) and personal oriented } \\
\text { valance significantly predict initiative selling } \\
\text { efforts. Additionally, employees who are } \\
\text { satisfied with their organizations direction and } \\
\text { practices are also likely to increase their initiative } \\
\text { selling efforts. }\end{array}$ \\
\hline $\begin{array}{l}\text { De Jong et al. } \\
\text { (2013) }\end{array}$ & $\begin{array}{l}\text { Ent Theory and } \\
\text { Practice }\end{array}$ & Job design as driver & $\begin{array}{l}\text { Which job characteristics influence } \\
\text { individual entrepreneurial behaviour }\end{array}$ & $\begin{array}{l}\text { Employees are more likely to be innovative and } \\
\text { proactive when they are given considerable job } \\
\text { autonomy. }\end{array}$ \\
\hline $\begin{array}{l}\text { Globocnik and } \\
\text { Salomo (2015) }\end{array}$ & $\begin{array}{l}\text { J. of Product } \\
\text { Innovation }\end{array}$ & $\begin{array}{l}\text { Organizational and Individual } \\
\text { drivers }\end{array}$ & $\begin{array}{l}\text { Is boot-legging behavior influenced } \\
\text { by formal management practices. }\end{array}$ & $\begin{array}{l}\text { Intrapreneurial self-efficacy, strategic autonomy, } \\
\text { and rewards for innovation accomplishments } \\
\text { foster bootlegging. Front-end formality has a } \\
\text { positive effect on bootlegging by increasing } \\
\text { intrapreneurial self-efficacy, but it reduces the }\end{array}$ \\
\hline
\end{tabular}




\begin{tabular}{|c|c|c|c|c|}
\hline & & & & $\begin{array}{l}\text { likelihood that employees will ignore formal } \\
\text { structures when promoting their ideas and } \\
\text { gathering their own resources to support their } \\
\text { bootlegging efforts }\end{array}$ \\
\hline $\begin{array}{l}\text { Heinonen and } \\
\text { Toivonen } \\
\text { (2008) }\end{array}$ & $\begin{array}{l}\text { Leadership and } \\
\text { Org } \\
\text { Development J. }\end{array}$ & $\begin{array}{l}\text { Organizational and Individual } \\
\text { drivers }\end{array}$ & $\begin{array}{l}\text { How employee attitudes influence } \\
\text { management behaviour in a CE } \\
\text { setting. }\end{array}$ & $\begin{array}{l}\text { CE in organizations is sparked by self-confident } \\
\text { Corporate Entrepreneurs with initiative who } \\
\text { challenge the status quo by questioning existing } \\
\text { working methods. Bottom up straight forward } \\
\text { communication by Corporate Entrepreneurs to } \\
\text { managers helps enhance this process. }\end{array}$ \\
\hline $\begin{array}{l}\text { Hornsby et al. } \\
\text { (2009) }\end{array}$ & $\begin{array}{l}\text { J. Business } \\
\text { Venturing }\end{array}$ & $\begin{array}{l}\text { Organizational and job design } \\
\text { drivers }\end{array}$ & $\begin{array}{l}\text { Are organisational factors that } \\
\text { support entrepreneurial action } \\
\text { supportive to all? }\end{array}$ & $\begin{array}{l}\text { Entrepreneurial actions vary with respect to } \\
\text { organizational positioning. Specifically work } \\
\text { discretion and management support is positive } \\
\text { for the entrepreneurial actions of Senior and } \\
\text { Middle managers }\end{array}$ \\
\hline $\begin{array}{l}\text { Kuratko et al. } \\
\text { (2005b) }\end{array}$ & $\begin{array}{l}\text { Int. Ent. and } \\
\text { Mgnt }\end{array}$ & $\begin{array}{l}\text { Organizational and Individual } \\
\text { drivers }\end{array}$ & $\begin{array}{l}\text { How a firms corporate environment } \\
\text { influences managers decision to } \\
\text { implement entrepreneurial actions }\end{array}$ & $\begin{array}{l}\text { Corporate environments which allow for greater } \\
\text { work discretion and positively reinforce } \\
\text { entrepreneurial behaviour, lead to heightened job } \\
\text { satisfaction among managers and subsequently } \\
\text { increased entrepreneurial actions on their behalf }\end{array}$ \\
\hline $\begin{array}{l}\text { Moriano et al. } \\
\text { (2014) }\end{array}$ & $\begin{array}{l}\text { Int. Ent. and } \\
\text { Mgnt }\end{array}$ & $\begin{array}{l}\text { Organizational and Individual } \\
\text { drivers }\end{array}$ & $\begin{array}{l}\text { How does managerial leadership } \\
\text { styles influence employee } \\
\text { entrepreneurial behaviour }\end{array}$ & $\begin{array}{l}\text { The effects of managements leadership style on } \\
\text { employee intrapreneurial behaviour is mediated } \\
\text { by employees identification with the organisation }\end{array}$ \\
\hline $\begin{array}{l}\text { Park et al. } \\
\text { (2014) }\end{array}$ & $\begin{array}{l}\text { Mgnt Comm. } \\
\text { Quarterly }\end{array}$ & $\begin{array}{l}\text { Organizational and Individual } \\
\text { drivers }\end{array}$ & $\begin{array}{l}\text { How organizations can increase } \\
\text { employee intrapreneurial behaviour }\end{array}$ & $\begin{array}{l}\text { A strong Organization-Employee Relationship } \\
\text { (OER) can motivate employees to engage in } \\
\text { intrapreneurship }\end{array}$ \\
\hline $\begin{array}{l}\text { Rigtering and } \\
\text { Weitzel (2013) }\end{array}$ & $\begin{array}{l}\text { Int. Ent. and } \\
\text { Mgnt }\end{array}$ & Organizational drivers & $\begin{array}{l}\text { How individual employee behaviour } \\
\text { stimulates intrapreneurship }\end{array}$ & $\begin{array}{l}\text { Organisational designs and willingness to } \\
\text { provide resources stimulates employee } \\
\text { intrapreneurial behaviours. These are enhanced } \\
\text { when employees have significant trust in their } \\
\text { management. Not all of employee intrapreneurial } \\
\text { behaviours are effectively translated into }\end{array}$ \\
\hline
\end{tabular}




\begin{tabular}{|c|c|c|c|c|}
\hline & & & & intrapreneurial projects. \\
\hline $\begin{array}{l}\text { Rutherfold and } \\
\text { Holt (2007) }\end{array}$ & $\begin{array}{l}\text { J. Org Change } \\
\text { Mgnt }\end{array}$ & $\begin{array}{l}\text { Organizational and Individual } \\
\text { drivers }\end{array}$ & $\begin{array}{l}\text { Whether process, individual and } \\
\text { contextual factors influence } \\
\text { individual and organisational-level } \\
\text { CE }\end{array}$ & $\begin{array}{l}\text { Employees individual characteristics and } \\
\text { supportive management process, rather context } \\
\text { influence their innovativeness. Subsequently, } \\
\text { employee innovativeness also increases their job } \\
\text { satisfaction }\end{array}$ \\
\hline $\begin{array}{l}\text { Sebora and } \\
\text { Theerapatvong } \\
\text { (2010) }\end{array}$ & $\begin{array}{l}\text { Int. Ent. and } \\
\text { Mgnt }\end{array}$ & $\begin{array}{l}\text { Organisational and external } \\
\text { drivers }\end{array}$ & $\begin{array}{l}\text { Which organisational and external } \\
\text { environment characteristics } \\
\text { influence managers idea generation, } \\
\text { risk taking and proactiveness }\end{array}$ & $\begin{array}{l}\text { Internal organisational, firm and external } \\
\text { environmental characteristics have differenitial } \\
\text { influences on the types of managers } \\
\text { entrepreneurial behaviour (idea generation, risk } \\
\text { taking and proactiveness). }\end{array}$ \\
\hline $\begin{array}{l}\text { Sieger et al. } \\
\text { (2013) }\end{array}$ & J. Mgnt Studies & $\begin{array}{l}\text { Organizational, Individual and } \\
\text { job design drivers }\end{array}$ & $\begin{array}{l}\text { Does the absence of formal } \\
\text { ownership rights help to align the } \\
\text { interests of senior managers with } \\
\text { those of owners. }\end{array}$ & $\begin{array}{l}\text { Senior managers entrepreneurial behaviour } \\
\text { mediates the relationship between their } \\
\text { ownership feelings and company performance. } \\
\text { Such behaviour however is determined by the } \\
\text { extent of monitoring they experience by owners. }\end{array}$ \\
\hline $\begin{array}{l}\text { Valsania et al. } \\
\text { (2014) }\end{array}$ & $\begin{array}{l}\text { Int. Ent. and } \\
\text { Mgnt }\end{array}$ & $\begin{array}{l}\text { Organizational and Individual } \\
\text { drivers }\end{array}$ & $\begin{array}{l}\text { How managers authentic leadership } \\
\text { style influences employee } \\
\text { entrepreneurial behaviour }\end{array}$ & $\begin{array}{l}\text { Managers' authentic leadership styles can help } \\
\text { employees develop a strong sense of } \\
\text { empowerment and identification with the } \\
\text { organisation. These can in turn motivate } \\
\text { employees to engage in intrapreneurial } \\
\text { behaviour. }\end{array}$ \\
\hline $\begin{array}{l}\text { Wakkee et al. } \\
\text { (2010) }\end{array}$ & $\begin{array}{l}\text { Int. Ent. and } \\
\text { Mgnt }\end{array}$ & $\begin{array}{l}\text { Organizational and Individual } \\
\text { drivers }\end{array}$ & $\begin{array}{l}\text { How does coaching by middle } \\
\text { managers enhance the } \\
\text { entrepreneurial behaviour of } \\
\text { operational level managers }\end{array}$ & $\begin{array}{l}\text { Both coaching and self-efficacy can enhance } \\
\text { entrepreneurial behaviour via reducing role } \\
\text { conflicts and through helping employees realize } \\
\text { what they can and cant do }\end{array}$ \\
\hline $\begin{array}{l}\text { Zampetakis } \\
\text { and Moustakis } \\
\text { (2007) }\end{array}$ & $\begin{array}{l}\text { Int J. Ent. } \\
\text { Behaviour and } \\
\text { Research }\end{array}$ & Organizational drivers & $\begin{array}{l}\text { How does organisational, individual } \\
\text { and job characteristics influence the } \\
\text { entrepreneurial tendency of front- } \\
\text { line Greek public servants }\end{array}$ & $\begin{array}{l}\text { Front-line public servants are more likely to } \\
\text { engage in entrepreneurial behaviour, when they } \\
\text { perceive that management is encouraging their } \\
\text { initiatives and sharing vital information with } \\
\text { them. Also, department heads have a higher } \\
\text { tendency towards entrepreneurial behaviour then } \\
\text { other types of employees. }\end{array}$ \\
\hline
\end{tabular}




\begin{tabular}{|l|l|l|l|l|}
\hline $\begin{array}{l}\text { Zampetakiset } \\
\text { al. (2009) }\end{array}$ & $\begin{array}{l}\text { European Mgnt. } \\
\text { J }\end{array}$ & $\begin{array}{l}\text { Organizational and Individual } \\
\text { drivers }\end{array}$ & $\begin{array}{l}\text { How an employees perceptions of } \\
\text { Organisational Support (OS) and } \\
\text { their Emotional Intelligence } \\
\text { influence their entrepreneurial } \\
\text { behaviour }\end{array}$ & $\begin{array}{l}\text { Employees who are Emotionally Intelligent and } \\
\text { perceive that their organisation is supporting } \\
\text { them are more likely to engage in entrepreneurial } \\
\text { behaviour. However, longer-tenured employees } \\
\text { tend to have a more negative perception } \\
\text { regarding the extent to which their organisations } \\
\text { supports them, thus curtailing their } \\
\text { entrepreneurial behaviour. }\end{array}$ \\
\hline $\begin{array}{l}\text { Zampetakis } \\
\text { and Moustakis } \\
\text { (2010) }\end{array}$ & $\begin{array}{l}\text { Int. J. } \\
\text { Manpower }\end{array}$ & Organizational drivers & $\begin{array}{l}\text { Which factors stimulate } \\
\text { entrepreneurial behaviour in the } \\
\text { Greek Public sector }\end{array}$ & $\begin{array}{l}\text { Civil servants who had confirmed employment } \\
\text { security, were provided with training, rewarded } \\
\text { appropriately and whose jobs are regularly } \\
\text { rotated reported higher levels of entrepreneurial } \\
\text { behaviour }\end{array}$ \\
\hline
\end{tabular}

Table 1: Overview of Key Empirical Studies on Employee Entrepreneurial Behavior 


\begin{tabular}{|c|c|c|c|c|c|}
\hline & Method & \multicolumn{2}{|c|}{ Sample Characteristics } & \multicolumn{2}{|c|}{ Employee Entrepreneurial Behavior } \\
\hline Authors & Method/Article Type & $\begin{array}{l}\text { Size and Type of } \\
\text { Firms Sampled }\end{array}$ & Respondents & Terminology & $\begin{array}{c}\text { Core Dimensions of } \\
\text { Entrepreneurial } \\
\text { Behavior }\end{array}$ \\
\hline $\begin{array}{l}\text { Amo and } \\
\text { Kolvereid (2005) }\end{array}$ & Quantitative/ Confirmatory & $\begin{array}{l}\text { N/A - Various } \\
\text { Sectors }\end{array}$ & All levels & Innovative Behaviour & Innovative Behaviour \\
\hline $\begin{array}{l}\text { Belousova and } \\
\text { Gailly (2013) }\end{array}$ & Qualitative/Explorative & Large - N/A & Various Levels & $\begin{array}{l}\text { Dispersed Corporate } \\
\text { Entrepreneurship }\end{array}$ & $\begin{array}{l}\text { Discovering, } \\
\text { evaluating, } \\
\text { legitimatizing and } \\
\text { exploiting } \\
\text { entrepreneurial } \\
\text { opportunities and ideas. }\end{array}$ \\
\hline $\begin{array}{l}\text { Brunaker and } \\
\text { Kurvinen (2006) }\end{array}$ & Qualitative/Explorative & $\begin{array}{l}\text { N/A - } \\
\text { Manufacturing }\end{array}$ & $\begin{array}{l}\text { Middle } \\
\text { Management }\end{array}$ & Intrapreneur & $\begin{array}{l}\text { Introducing local } \\
\text { initiatives }\end{array}$ \\
\hline $\begin{array}{l}\text { Croonen et al. } \\
(2014)\end{array}$ & Quantitative/ Confirmatory & $\begin{array}{l}\text { N/A - Service } \\
\text { Sector }\end{array}$ & $\begin{array}{l}\text { Senior } \\
\text { Management }\end{array}$ & $\begin{array}{l}\text { Entrepreneurial } \\
\text { behavior }\end{array}$ & $\begin{array}{l}\text { Strategic renewal and } \\
\text { innovativeness }\end{array}$ \\
\hline $\begin{array}{l}\text { De Clerq et al } \\
\text { (2011) }\end{array}$ & Quantitative/ Confirmatory & $\begin{array}{l}\text { Large - Service } \\
\text { Sector }\end{array}$ & Managers & $\begin{array}{c}\text { Entrepreneurial } \\
\text { initiatives }\end{array}$ & Initiative Selling \\
\hline $\begin{array}{l}\text { De Jong et al. } \\
\text { (2013) }\end{array}$ & Quantitative/ Confirmatory & $\begin{array}{l}\text { Medium - Service } \\
\text { Sector }\end{array}$ & All levels & $\begin{array}{l}\text { Entrepreneurial } \\
\text { behavior }\end{array}$ & $\begin{array}{l}\text { Individual initiative } \\
\text { taking, risk taking and } \\
\text { innovativeness }\end{array}$ \\
\hline $\begin{array}{l}\text { Globocnik and } \\
\text { Salomo (2015) }\end{array}$ & Quantitative/ Confirmatory & $\begin{array}{l}\text { Various Sizes and } \\
\text { Sectors }\end{array}$ & All levels & Boot-Legging & Idea generation \\
\hline $\begin{array}{l}\text { Heinonen and } \\
\text { Toivonen (2008) }\end{array}$ & Quantitative/ Confirmatory & $\begin{array}{l}\text { Medium - Public } \\
\text { Sector }\end{array}$ & All levels & $\begin{array}{l}\text { Corporate } \\
\text { Entrepreneur }\end{array}$ & $\begin{array}{l}\text { Supporting the } \\
\text { innovative actions of } \\
\text { others; inspiring } \\
\text { enthusiasm and trust } \\
\text { among subordinates; } \\
\text { rewarding others for } \\
\text { entrepreneurial efforts }\end{array}$ \\
\hline $\begin{array}{l}\text { Hornsby et al. } \\
\text { (2009) }\end{array}$ & Quantitative/ Confirmatory & $\begin{array}{l}\text { N/A - Various } \\
\text { Sectors }\end{array}$ & Managers & $\begin{array}{l}\text { Entrepreneurial } \\
\text { Actions }\end{array}$ & Idea generation \\
\hline $\begin{array}{l}\text { Kuratko et al. } \\
\text { (2005) }\end{array}$ & Quantitative/ Confirmatory & $\begin{array}{l}\text { N/A - Various } \\
\text { Sectors }\end{array}$ & Managers & $\begin{array}{l}\text { Entrepreneurial } \\
\text { actions }\end{array}$ & $\begin{array}{l}\text { Number of new ideas } \\
\text { proposed and } \\
\text { implemented }\end{array}$ \\
\hline $\begin{array}{l}\text { Moriano et al. } \\
(2014)\end{array}$ & Quantitative/ Confirmatory & $\begin{array}{l}\text { Medium/Large - } \\
\text { Various Sectors }\end{array}$ & All levels & $\begin{array}{l}\text { Intrapreneurial } \\
\text { Behaviour }\end{array}$ & $\begin{array}{l}\text { Individual } \\
\text { proactiveness, risk } \\
\text { taking and }\end{array}$ \\
\hline
\end{tabular}




\begin{tabular}{|c|c|c|c|c|c|}
\hline & & & & & innovativeness \\
\hline Park et al. (2014) & Quantitative/ Confirmatory & $\begin{array}{l}\text { Medium/Large - } \\
\text { Various Sectors }\end{array}$ & All levels & Intrapreneurship & $\begin{array}{l}\text { new businesses, } \\
\text { product/service } \\
\text { innovation, } \\
\text { process/technology } \\
\text { innovation and self- } \\
\text { renewal }\end{array}$ \\
\hline $\begin{array}{l}\text { Rigtering and } \\
\text { Weitzel (2013) }\end{array}$ & Quantitative/ Confirmatory & $\begin{array}{l}\text { SME/Large - } \\
\text { Various Sectors }\end{array}$ & All levels & $\begin{array}{l}\text { Intrapreneurial } \\
\text { Behaviour }\end{array}$ & $\begin{array}{l}\text { Individual } \\
\text { proactiveness, risk } \\
\text { taking and } \\
\text { innovativeness }\end{array}$ \\
\hline $\begin{array}{l}\text { Rutherfold and } \\
\text { Holt (2007) }\end{array}$ & Quantitative/ Confirmatory & $\begin{array}{l}\text { Medium - Public } \\
\text { Sector }\end{array}$ & All levels & Innovation behaviour & Innovativeness \\
\hline $\begin{array}{l}\text { Sieger et al. } \\
\text { (2013) }\end{array}$ & Quantitative/ Confirmatory & $\begin{array}{l}\text { Medium - Various } \\
\text { Sectors }\end{array}$ & $\begin{array}{l}\text { Senior } \\
\text { Management }\end{array}$ & $\begin{array}{l}\text { Entrepreneurial } \\
\text { behavior }\end{array}$ & $\begin{array}{l}\text { Creating new or } \\
\text { reconfiguring existing } \\
\text { opportunities; } \\
\text { Scanning environment } \\
\text { for opportunities and } \\
\text { threats; Recognizing, } \\
\text { surfacing and } \\
\text { generating innovative } \\
\text { ideas by observing } \\
\text { trends; Helping others } \\
\text { to behave } \\
\text { entrepreneurially }\end{array}$ \\
\hline $\begin{array}{l}\text { Sebora and } \\
\text { Theerapatvong } \\
\text { (2010) }\end{array}$ & Quantitative/ Confirmatory & $\begin{array}{l}\text { Medium/Large - } \\
\text { Manufacturing } \\
\text { Sector }\end{array}$ & $\begin{array}{l}\text { Middle and } \\
\text { Senior } \\
\text { Management }\end{array}$ & $\begin{array}{l}\text { Corporate } \\
\text { Entrepreneurship }\end{array}$ & $\begin{array}{l}\text { Individual } \\
\text { proactiveness, risk } \\
\text { taking and } \\
\text { innovativeness }\end{array}$ \\
\hline $\begin{array}{l}\text { Valsania et al. } \\
\text { (2014) }\end{array}$ & Quantitative/ Confirmatory & $\begin{array}{l}\text { Medium/Large - } \\
\text { Various Sectors }\end{array}$ & All levels & $\begin{array}{l}\text { Intrapreneurial } \\
\text { Behavior }\end{array}$ & $\begin{array}{l}\text { Individual } \\
\text { proactiveness, risk } \\
\text { taking and } \\
\text { innovativeness }\end{array}$ \\
\hline $\begin{array}{l}\text { Wakkee et al. } \\
\text { (2010) }\end{array}$ & Quantitative/ Confirmatory & $\begin{array}{l}\text { Large - Service } \\
\text { Sector }\end{array}$ & $\begin{array}{l}\text { Middle and } \\
\text { Operational } \\
\text { level } \\
\text { Management }\end{array}$ & $\begin{array}{l}\text { Entrepreneurial } \\
\text { Behaviour }\end{array}$ & $\begin{array}{l}\text { Individual } \\
\text { proactiveness, risk } \\
\text { taking and } \\
\text { innovativeness }\end{array}$ \\
\hline $\begin{array}{l}\text { Zampetakis and } \\
\text { Moustakis (2007) }\end{array}$ & Quantitative/ Confirmatory & $\begin{array}{l}\text { N/A - Public } \\
\text { Sector }\end{array}$ & $\begin{array}{l}\text { Rank and file } \\
\text { employees }\end{array}$ & $\begin{array}{l}\text { Entrepreneurial } \\
\text { behaviour }\end{array}$ & $\begin{array}{l}\text { Developing a strategic } \\
\text { vision; Creation of an } \\
\text { energetic working }\end{array}$ \\
\hline
\end{tabular}




\begin{tabular}{|l|l|l|l|l|l|}
\hline & & & & & $\begin{array}{l}\text { environment; Being } \\
\text { change orientated }\end{array}$ \\
\hline $\begin{array}{l}\text { Zampetakiset al. } \\
\text { (2009) }\end{array}$ & Quantitative/ Confirmatory & $\begin{array}{l}\text { N/A - Public } \\
\text { Sector }\end{array}$ & All levels & $\begin{array}{l}\text { Entrepreneurial } \\
\text { behaviour }\end{array}$ & $\begin{array}{l}\text { Ability to cut through } \\
\text { red tape; Developing a } \\
\text { strategic vision; } \\
\text { Creation of an energetic } \\
\text { working environment; } \\
\text { Being change } \\
\text { orientated }\end{array}$ \\
\hline $\begin{array}{l}\text { Zampetakis and } \\
\text { Moustakis (2010) }\end{array}$ & Quantitative/ Confirmatory & $\begin{array}{l}\text { N/A - Public } \\
\text { Sector }\end{array}$ & All levels & $\begin{array}{l}\text { Entrepreneurial } \\
\text { behaviour }\end{array}$ & $\begin{array}{l}\text { Ability to cut through } \\
\text { red tape; Developing a } \\
\text { strategic vision; } \\
\text { Creation of an energetic } \\
\text { working environment; } \\
\text { Being change } \\
\text { orientated }\end{array}$ \\
\hline
\end{tabular}

Table 2: Methodological and Conceptual Characteristics of Key Studies 


\begin{tabular}{|c|c|c|c|}
\hline $\begin{array}{c}\text { Contextual } \\
\text { Determinant }\end{array}$ & Definition & Sub Category & Key References \\
\hline Job/Role & $\begin{array}{l}\text { Specific aspects and } \\
\text { characteristics of an } \\
\text { employee's job or role } \\
\text { which may or may not } \\
\text { motivate them to } \\
\text { engage in } \\
\text { entrepreneurial } \\
\text { behavior }\end{array}$ & $\begin{array}{l}\text { Autonomy/discretion; } \\
\text { Tenure; Free time; } \\
\text { Networks }\end{array}$ & $\begin{array}{l}\text { De Jong et al., 2013; Kuratko et } \\
\text { al., 2005b; Hornsby et al., 2009; } \\
\text { Zampetakis and Moustakis, } \\
\text { 2007; Globocnik and Salomo, } \\
\text { 2015; Belousova and Gailly, } \\
\text { 2013; Rigtering et al., 2013; } \\
\text { Zampetakis et al., 2009; } \\
\text { Zampetakis and Moustakis, } \\
\text { 2010; Brunaker and Kurvinen } \\
\text { (2006) }\end{array}$ \\
\hline Work/Organizational & $\begin{array}{l}\text { Elements and } \\
\text { characteristics of the } \\
\text { broader organizational } \\
\text { and work environment } \\
\text { which may or may not } \\
\text { motivate employees to } \\
\text { engage in } \\
\text { entrepreneurial } \\
\text { behavior; } \\
\text { Entrepreneurial cultures } \\
\text { which }\end{array}$ & $\begin{array}{l}\text { Culture, management } \\
\text { support; leadership; } \\
\text { rewards; } \\
\text { communication; process; } \\
\text { structures }\end{array}$ & $\begin{array}{l}\text { Amo and Kolvereid, 2005; Park } \\
\text { et al., 2014; Kurtako et al., } \\
\text { 2005b; Rutherford and Holt, } \\
\text { 2007; Belousova and Gailly, } \\
\text { 2013; Moriano et al., 2014; } \\
\text { Rigtering and Weitzel (2013); } \\
\text { Valsania et al. 2014; Globocnik } \\
\text { and Salomo, 2015; Heinonen } \\
\text { and Toivonen, 2008; Zampetakis } \\
\text { and Moustakis, 2007; Wakkee et } \\
\text { al. 2010; De Clercq et al., 2011; } \\
\text { Sebora and Theeraptvong, 2010; } \\
\text { Zampetakis et al., 2009; Sieger } \\
\text { et al., 2013; Zampetakis and } \\
\text { Moustakis, 2010; }\end{array}$ \\
\hline $\begin{array}{l}\text { Firm characteristics } \\
\text { and external } \\
\text { environment }\end{array}$ & $\begin{array}{l}\text { Characteristics of firms } \\
\text { and employees } \\
\text { perceptions of the } \\
\text { external environment } \\
\text { which may or may not } \\
\text { motivate employees to } \\
\text { engage in } \\
\text { entrepreneurial } \\
\text { behavior }\end{array}$ & $\begin{array}{l}\text { Firm Size; Type; } \\
\text { Competitiveness; } \\
\text { Resource Endowments }\end{array}$ & $\begin{array}{l}\text { Sebora and Theerapatvong, } \\
\text { 2009; Croonen et al., } 2016\end{array}$ \\
\hline
\end{tabular}

Table 3: Contextual Determinants of Employee Entrepreneurial Behavior 
Job/Role Context

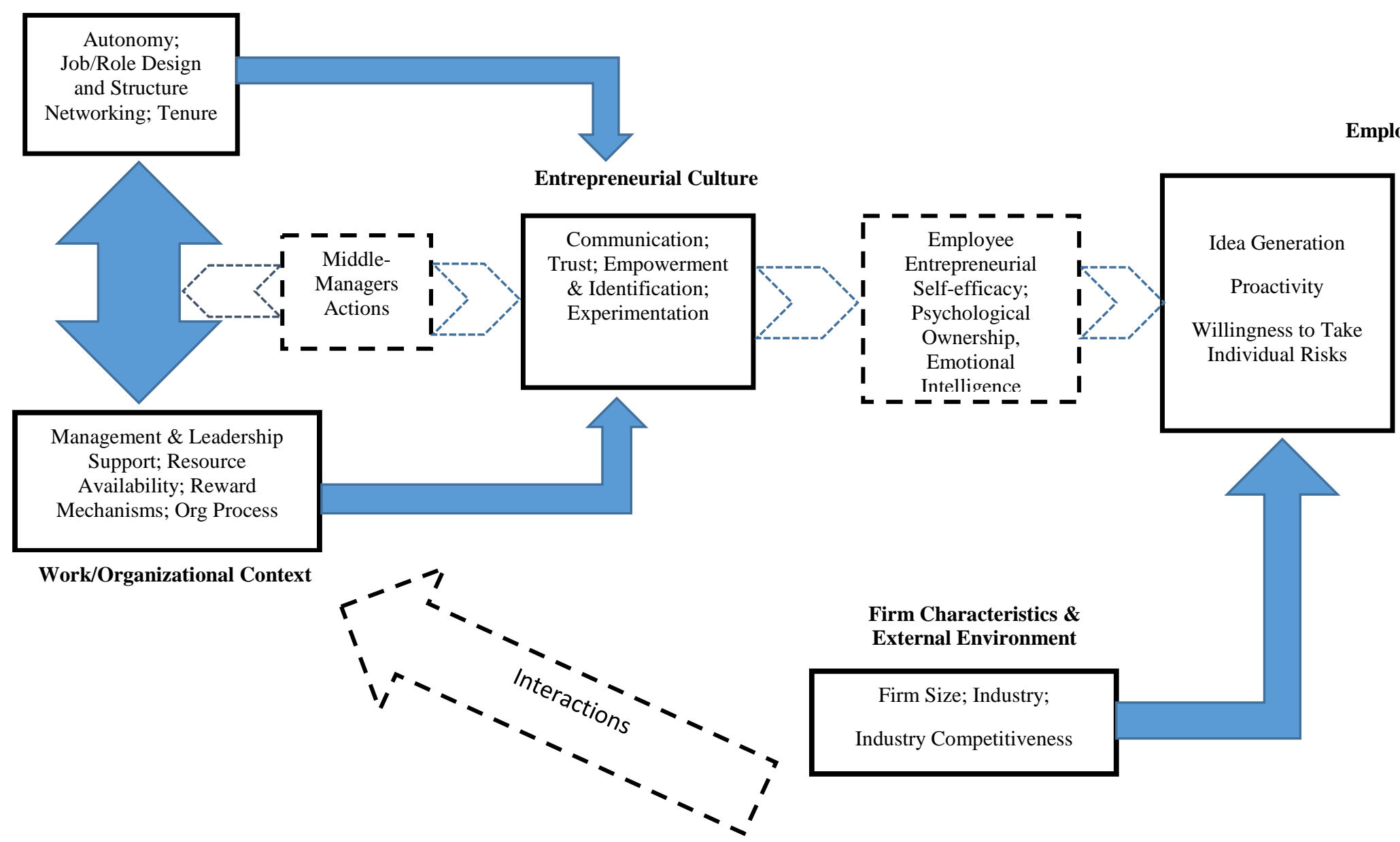

Figure 1: Synthesis of Key SLR Findings and Directions for Future Research 